\title{
Responses to various protein and energy supplements by steers fed low-quality tropical hay. 2. Effect of stage of maturity of steers
}

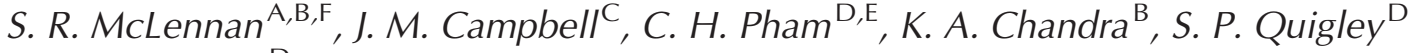 \\ and D. P. Poppi ${ }^{\mathrm{D}}$ \\ ${ }^{A}$ The University of Queensland, Centre for Animal Science, Queensland Alliance for Agriculture and Food \\ Innovation, GPO Box 267, Brisbane, Qld 4001, Australia. \\ ${ }^{B}$ Department of Agriculture and Fisheries, GPO Box 267, Brisbane, Qld 4001, Australia. \\ ${ }^{\mathrm{C}}$ Department of Agriculture and Fisheries, Brian Pastures Research Station, PO Box 118, Gayndah, Qld 4625, \\ Australia. \\ DThe University of Queensland, Schools of Agriculture and Food Sciences, and Veterinary Science, Gatton, \\ Qld 4343, Australia. \\ EPresent address: Ministry of Agriculture and Rural Development, National Institute of Animal Science, \\ Thuyphuong, Bac Tuliem, Hanoi, Vietnam. \\ FCorresponding author. Email: s.mclennan@uq.edu.au
}

\begin{abstract}
Dose response curves to various supplements were established in two pen-feeding experiments (Exp1 and Exp2) with Bos indicus crossbred steers of two age groups (Young, 10-12 months; Old, 33-36 months) fed low-quality tropical grass hays ad libitum. Diets included supplements based on (Exp1) cottonseed meal (CSM; intake (as fed) 0-10 g/kg liveweight (W).day) and a barley mix (Bar; 0-20 g/kg W.day) and (Exp2) a molasses mix (MUP) and a Bar mix, both fed at $0-20 \mathrm{~g} / \mathrm{kg}$ W.day. Urea was provided with the Bar mixes and urea/copra meal with the MUP mix. Growth rates of Young steers increased linearly with Bar and MUP supplements but asymptotically with CSM whereas those of Old steers increased asymptotically with all supplement types. With supplement intake expressed on a liveweight basis $(\mathrm{g} / \mathrm{kg}$ W.day), responses were greater for both steer age groups with CSM compared with Bar (Young, $P<0.001 ;$ Old, $P<0.01$ ) and Bar compared with MUP treatments (Young, $P<0.01$; Old, $P<0.05$ ). Furthermore, Old steers outperformed their Young counterparts with both CSM $(P<0.05)$ and Bar $(P<0.001)$ supplements fed in Exp1 and with Bar and MUP supplements $(P<0.01)$ fed in Exp2. When supplement intake was expressed in absolute terms $(\mathrm{kg} / \mathrm{day})$, growth responses were not different between age groups for different supplements except that Old steers had a higher daily $\mathrm{W}$ gain on Bar than their Young counterparts $(P<0.05)$. Intake of hay (W-corrected) was higher for Young compared with Old steers without supplement but was variably reduced for both steer groups with increasing supplement intake. The results of these experiments have implications for supplement formulation for steers at different stages of maturity grazing low-quality forages.
\end{abstract}

Additional keywords: cattle age, digestibility, energy retention, metabolisable energy intake, plasma urea, rumen ammonia, substitution effects.

Received 28 September 2015, accepted 24 November 2015, published online 22 March 2016

\section{Introduction}

Access to higher-value domestic and export markets for beef in northern Australia, for instance for carcasses compliant with Meat Standards Australia grading, will be mainly restricted to cattle finished at weights in excess of $500 \mathrm{~kg}$ at less than 3 years of age. However, the low annual growth rates and highly seasonal production of cattle grazing native pastures in the region puts this target beyond reach of a large proportion of beef producers (Bortolussi et al. 2005) unless access is provided to improved pasture species or nutritional supplements are provided (Fordyce et al. 2009). Low or negative growth of cattle in the dry winter/ spring months, in particular, constrains annual liveweight (W) gain and even when cattle are slaughtered relatively young at $\sim 3$ years of age, they will endure at least two such dry seasons post-weaning. Most feeding strategies target this dry season period.

The optimum age to feed cattle in northern Australia is not clear. The options are to feed supplements early in the growth path when the cattle are young and supposedly have high growth potential or later when they are at a more advanced stage of maturity and closer to finishing, or a combination of both. From an economic viewpoint the decision will be influenced by the 
responsiveness of cattle at the different ages to the provision of additional nutrients but also by the extent of any erosion of growth responses by compensatory growth in the wet seasons following dry season feeding, which is also influenced by the age of the cattle (Ryan 1990). The changes in body composition with advancing stage of maturity of cattle have been well documented (see, for example, NRC 1996); principally, an increase in body fat and a decrease in protein content as a proportion of total body mass. These compositional changes are translated to nutritional and economic efficiencies of feeding through the conflicting effects of the higher energy costs of deposition of protein relative to fat (MacRae and Lobley 1982; Butler-Hogg and Cruickshank 1989; Poppi 1990), against the higher conversion of energy to $\mathrm{W}$ gain with protein compared with fat accretion largely through the association of water with protein in lean tissue deposition (NRDR 2007). A likely consequence of these age-related body compositional changes is that different combinations of nutrients will be required, favouring a diet with high protein for lean growth in young cattle (Ørskov 1970) and one providing glucogenic precursors for fat synthesis in older cattle (MacRae and Lobley 1982). In support, tables provided by AFRC (1993) of metabolisable protein (MP) and metabolisable energy (ME) requirements for cattle (diet energy density $11 \mathrm{MJ} / \mathrm{kg}$ dry matter (DM)) stipulate a MP/ME (g/MJ) of 6.2, 4.6 and 4.3 for steers of 200,400 and $500 \mathrm{~kg} \mathrm{~W}$, respectively, growing at $1 \mathrm{~kg} /$ day. Practical evidence in support of these theoretical differences in nutrient requirements and growth responses with age of cattle consuming low-quality forage diets is not easily extricated from the literature.

Results described in the previous paper of this series (McLennan et al. 2017) indicated that young steers $(\sim 200 \mathrm{~kg}$ W) showed higher growth responses to protein meal than to 'energy sources' such as grains and molasses when supplement intakes were low ( $<5 \mathrm{~g} / \mathrm{kg} \mathrm{W}$.day) but as intakes increased the response curves to the different supplement types tended to converge. Within the energy sources, the growth response declined in order of barley, sorghum and molasses. The experiments described in the present paper were designed to complement this previous study by comparing the dose response curves for young and older cattle to various supplements which provide different combinations of protein and energy, in order to provide practical information for commercial feeding situations typical of those encountered in northern Australia.

\section{Materials and methods}

Two pen-feeding experiments, hereafter Exp1 and Exp2, were carried out at Brian Pastures Research Station near Gayndah, Queensland. As the experimental design and procedures were similar for both experiments, the description of methodology below refers to both except where otherwise indicated. The experiments were carried out with endorsement by the Staff Access Animal Ethics Committee of the Department of Agriculture and Fisheries, Queensland with approval references SA-2008/09/263 and SA-2010/09/328, respectively.

\section{Animals, treatments and experimental design}

For both experiments, Brahman crossbred steers ( 5/8 Bos indicus content) of two age groups but of the same genetic origin were sourced from the Swans Lagoon Research Station herd in north Queensland, $120 \mathrm{~km}$ south-east of Townsville. The ages of the steers in both experiments were $\sim 10-12$ months (hereafter Young) and 33-36 months (hereafter Old). There was a 2-year time separation between Exp1 and Exp2. At the commencement of the experiments the average $\mathrm{W}$ of the steers was 195.5 ( \pm 7.00 ; s.d.) and $424.6( \pm 18.87)$, and $203.3( \pm 7.43)$ and $440.1( \pm 16.38) \mathrm{kg}$, for Young and Old steers in Exp1 and Exp2, respectively. A basal diet of low-quality hay was offered ad libitum to all steers, this being pangola grass (Digitaria eriantha subspecies Pentzii) in Exp1 and black speargrass (Heteropogon contortus) in Exp2. The experimental design was a randomised block incorporating response relationships with two age groups $\times$ two supplement types $\times$ four levels of supplement feeding, with from two to four replicates (steers) per level of supplementation (see below), plus unsupplemented Control steers within each age group. Steers were maintained in the same individual pens throughout the experiments, with 42-44 pens used in total.

In Exp1, rations included supplements based on either barley grain mix plus urea-sulfur (hereafter Bar) or cottonseed meal (hereafter CSM). The Bar mix was formulated by thoroughly mixing coarsely cracked (roller-milled) barley $(943.4 \mathrm{~g} / \mathrm{kg}$; as fed), salt (9.4), limestone (9.4), molasses (18.9) and water (18.9). Steers offered the Bar supplement also received 200 (Young) or 440 (Old) g/day of a urea-ammonium sulfate solution (urea-S) formulated to balance rumen-degradable nitrogen (RDN) with digestible organic matter (DOM) supply in the rumen. This solution contained, by weight as fed $(\mathrm{g} / \mathrm{kg}), 204.5$ urea, 45.5 ammonium sulfate (Gran-am; Incitec Pivot Ltd, Melbourne, Vic., Australia) and 750 water (overall $\mathrm{N}: \mathrm{S}=9.5$ ) so that the steers received 40.9 (Young) or 90.0 (Old) g urea/day. The CSM supplement was fed without additives. The Bar mix was offered at 5, 10, 15 and $20 \mathrm{~g} / \mathrm{kg} \mathrm{W.day} \mathrm{(as} \mathrm{fed)} \mathrm{whereas} \mathrm{the}$ CSM supplement was offered at the lower rates of 2.5, 5, 7.5 and $10 \mathrm{~g} / \mathrm{kg}$ W.day (as fed), based on responses from a previous experiment (McLennan et al. 2017). For each age group there were four unsupplemented Control steers and two steers for each supplement/feeding level except when Bar was fed at $20 \mathrm{~g} / \mathrm{kg} \mathrm{W}$.day, when three steers were used.

In Exp2, the two supplements used were a barley-based mix similar to that described for Exp1 (Bar) and a molasses-based mix containing urea and protein meal (MUP). The Bar mix differed slightly from that used in Exp 1 in that Rumensin 100 (active ingredient monensin at $100 \mathrm{~g} / \mathrm{kg}$; Elanco, Eli Lilly Australia Pty Ltd, Sydney, NSW, Australia) was added in order to be consistent in this respect with the MUP mix. Thus, the Bar mix comprised coarsely cracked (roller-milled) barley (943 g/kg; as fed), salt (9.4), limestone (9.4), molasses (18.9), water (18.8) and Rumensin 100 (0. 5). Steers on the Bar treatments also received the urea-S solution, as described for Exp1 above. The MUP mix contained molasses $(869 \mathrm{~g} / \mathrm{kg}$; as fed), urea (26), copra meal (87), salt (8.8), di-calcium phosphate (8.7) and Rumensin100 (0.5), and was thoroughly mixed mechanically for at least $20 \mathrm{~min}$ until the urea was completely dissolved. Both the Bar mix and the MUP mix were offered at 5, 10, 15 and $20 \mathrm{~g} / \mathrm{kg}$ W.day (as fed). For each age group there were three unsupplemented Control steers and two steers for each supplement/feeding level except with 
supplements fed at $20 \mathrm{~g} / \mathrm{kg} \mathrm{W}$.day when there were three Young and four Old steers.

\section{Procedures}

Each experiment consisted of a 6-day initial equilibration and a 70-day experimental period. During the initial equilibration period steers in excess of the number required were fed the basal hay ad libitum, without supplements, in group pens. At the end of this period, steers were weighed full and fasted ( $24 \mathrm{~h}$ off feed, $16 \mathrm{~h}$ off water) and the required number were allocated to treatments by stratified randomisation on the basis of the fasted W (Day 0). Within age groups steers were divided into two $\mathrm{W}$ classes at allocation with each class representing a block where the blocks were allocated to an area within the pen complex. Steers were allocated to pens randomly within blocks with Young and Old steers interspersed.

The hay was fed once daily (0800 hours) and total residues of hay and supplement were collected once weekly. Hay was fed to each steer at an amount estimated, after bunk inspection, to provide $\sim 15 \%$ in excess of its intake on the previous day thereby maintaining ad libitum intake. The urea-S solution was sprinkled on and mixed into the hay once daily soon after the hay was offered. The urea-S mix was offered separate from the Bar mix to reduce the possibility of urea toxicity in the event of rapid grain intake. The other supplements were offered in separate feeders from the hay to allow the intake of both dietary components to be accurately measured. The MUP mix was fed from a rubber trough mounted on the fence $\sim 2 \mathrm{~m}$ away from the hay to reduce transfer of hay to the supplement. The CSM and MUP supplements were fed once daily at the same time as the hay. In both experiments, the Bar mix was fed twice daily in equal quantities, $\sim 1 \mathrm{~h}$ after the hay was offered and again at 1600 hours, in order to reduce the rate of grain intake and the possibility of acidosis. For the same reason, the amount of Bar mix offered was slowly and incrementally increased to treatment rates over the first 10 days of each experiment. Each week the steers were weighed unfasted before feeding and the amount of supplement offered daily was adjusted, on an individual steer basis, on these new $\mathrm{W}$ to maintain a constant intake on a W basis. Representative samples of the hay and supplements offered were collected daily, and of the hay and supplement residues were collected weekly, bulked and dried to constant weight at $60^{\circ} \mathrm{C}$ to determine DM content. For the molasses and the MUP mix offered and refused, triplicate weighed subsamples were placed into aluminium trays to which were added approximately equal weights of water and weighed amounts of oven-dried paper towel used to take up the diluted molasses sample. This combination was then dried to constant weight at $60^{\circ} \mathrm{C}$ over $\sim 4$ days and DM content determined. This procedure was used to overcome the problems associated with whole molasses forming an outer crust upon heating, which prevents complete drying of the material. At the end of the 70-day experimental phase the steers were weighed full and fasted (as above). However, as in both experiments the $\mathrm{W}$ trends were found to be similar regardless of whether changes were determined on a full or fasted $\mathrm{W}$ basis, the $\mathrm{W}$ changes presented in this paper are for full weights.

From Days 43 to 49 of each experiment a total collection of the faeces from the concrete floor of each pen was undertaken at least three times daily. Each day the total faecal output of each steer was weighed, thoroughly mixed and a representative $10 \%$ by weight subsample was collected and stored at $-18^{\circ} \mathrm{C}$. After the final faecal collection, the daily subsamples for each individual steer were thawed, bulked and mechanically mixed. Duplicate subsamples were dried to a constant weight at $60^{\circ} \mathrm{C}$ and faecal DM output and the digestibility of DM (DMD) were determined for individual steers.

On Day 58 of each experiment, a 10-mL sample of blood was taken from the coccygeal vein of steers into heparinised glass tubes and placed on ice before centrifugation at $700 \mathrm{~g}$ for $15 \mathrm{~min}$ at $25^{\circ} \mathrm{C}$. The plasma was then stored at $-18^{\circ} \mathrm{C}$ before analysis for urea-N concentration (PUN). At the same time in Exp1 only, rumen fluid was collected per os under mild vacuum from all steers using a stomach tube and vacuum pump. The rumen fluid was strained through a nylon stocking and $4 \mathrm{~mL}$ of strained fluid was added to an equal volume of $0.2 \mathrm{~N}$ hydrochloric acid for the determination of ammonia-nitrogen $\left(\mathrm{NH}_{3}-\mathrm{N}\right)$ concentration. Prior to sampling, feeding was staggered in time so that sampling of each steer occurred $3 \mathrm{~h}$ after offering the hay, which coincided with $3 \mathrm{~h}$ after offering the CSM, MUP and urea-S and $2 \mathrm{~h}$ after offering the morning portion of the Bar mix supplements. The amount of CSM, MUP and the Bar mixes, but not hay or urea-S, consumed between feeding and rumen and blood sampling was also determined.

\section{Laboratory analyses}

Samples of hay, barley, Bar mixes and CSM were milled through a 1-mm screen before laboratory analysis. Those of the molasses and MUP supplement were analysed as collected. The methods of most laboratory analyses were described in the first paper of this series (McLennan et al. 2017), with the following exceptions. The $\mathrm{P}$ content was measured by a colourimetric method (AOAC 1980) following combustion at $600^{\circ} \mathrm{C}$ to a constant weight and digestion with concentrated hydrochloric acid. The $\mathrm{Ca}$ concentration was determined by atomic absorption spectroscopy using a nitrous oxide-acetylene flame following combustion of samples at $600^{\circ} \mathrm{C}$ for $3 \mathrm{~h}$ together with a concentrated hydrochloric acid digestion.

\section{Estimation of metabolisable energy intake (MEI) and energy retention (ER)}

The procedures for estimating MEI and ER were those described by McLennan et al. (2017). Briefly, MEI was calculated as the product of total DM intake and an estimate of the energy density $(\mathrm{M} / \mathrm{D})$ of the combined diet based on $\mathrm{DMD}$, using the equations from Freer et al. (2012), and ER was calculated as the net energy for gain using the measured $\mathrm{W}$ change and an estimate of the energy value of the $\mathrm{W}$ gain as provided by equations in NRDR (2007).

\section{Statistical analyses}

The methods of analysis were similar to those described in McLennan et al. (2017) with modifications to accommodate the two ages of steers. Statistical analyses were performed using regression analyses in Genstat (2015), with the significance level set at $5 \%$. The primary aim of the statistical analyses was to model and compare, for different supplement 
types and age groups, the dose response curves for different variables such as average daily gain, DMD and ER relative to measures of intake, for instance of supplement DM and total ME. In both experiments, comparisons were made between supplement types within age group and between age groups within supplement type. Analyses used the measured supplement intake (expressed on a DM basis) rather than that intended for each steer to account for uneaten supplement. Within age groups the Controls were considered as being zero supplement intake for both supplement types in both experiments. No statistical comparisons were made across experiments.

For each variable versus intake combination tested, a series of analyses were performed in order to determine the final response curve. A full regression model was performed which included steer age and both the linear and quadratic components for each supplement type within age group. Where the quadratic coefficients were not significantly different to zero $(P>0.05)$ they were removed from the model leaving a linear response. The models were then re-run to test the linear coefficients in the same manner. However, if the linear component was found to be non-significant it was still left in the model to show any potential trends. Once the degree of polynomial (linear or quadratic) was determined, separate regressions were performed to determine whether there were significant differences between supplement types within age group or between age groups within supplement types, for response curves of the same degree of polynomial. Where response curves for different supplement types were described by a different degree of polynomial, significant difference between treatments was assumed. However, in this instance, comparisons of supplement types within age groups or of age groups within supplement types were made at the quadratic level to demonstrate the ranking of supplements or age groups even though the quadratic factor was not significant. For response curves where MEI and not supplement intake was the independent variable, and $(\mathrm{X})$ values for the Control were not zero, the average Control value was subtracted from the data before analysis to allow use of the methodology described above. Quadratic response curves were replaced by asymptotic curves on a case-by-case basis if it seemed biologically meaningful. This approach was used to describe relationships between supplement and total DM intakes; the corresponding hay DM intake equations were determined by subtracting the supplement DM intake from this equation. The $R^{2}$ (adjusted) for each response curve relative to age was calculated along with its residual standard deviation to show how well each curve fitted the data.

\section{Results}

\section{Diet composition}

The chemical composition of the hays and supplements offered in Exp1 and Exp2 are shown in Table 1. The very low quality of the hays is evidenced by their low crude protein (31-42 g/ kg DM) and high neutral detergent fibre contents (>650 g/kg DM). The supplements fed provided a ready source of additional protein, in the order CSM, MUP and the Bar mixes, and additional fermentable energy as either digestible fibre, starch or soluble sugars.

\section{Intake of supplements and steer health}

\section{Exp1}

In general, the CSM supplement was completely consumed by the steers whereas at the higher levels of feeding of the Bar supplement, some steers did not consume their full allocation. There were two isolated, transient (3-4 days) and mild cases of acidosis in Old steers on the Bar treatments, as indicated by lethargy, reduced appetite and diarrhoea, but these steers recovered quickly and soon returned to previous grain intake levels. There were no obvious adverse effects from feeding the CSM.

\section{Exp2}

At low to medium levels of feeding, both supplement types were rapidly consumed by the steers. However, despite providing continuous access to supplements, the highest prescribed intakes (20 g/kg W.day, as fed) of either supplement were not achieved. There was one suspected case of acidosis in an Old steer fed the

Table 1. Chemical composition of the hay and supplements

Bar, barley-based mixes; MUP, molasses-based mix (see text for full composition of Bar and MUP mixes). OM, organic matter; N, nitrogen; NDF, neutral detergent fibre; ADF, acid detergent fibre; CF, crude fibre; EE, ether extract; Ca, calcium; $\mathrm{P}$, phosphorus; - , not determined

\begin{tabular}{lrrrrrrrrr}
\hline & OM & N & NDF & ADF & $\begin{array}{c}\text { CF } \\
\text { (g/kg DM) }\end{array}$ & EE & Starch & Ca & P \\
\hline Pangola grass hay & 942 & 6.7 & 653 & 364 & - & - & - & 1.6 & 2.0 \\
Cottonseed meal & 925 & 76.9 & 187 & 113 & 77 & 28 & - & 2.0 & 12.7 \\
Barley grain & 968 & 17.7 & 176 & - & 43 & 23 & 568 & $<1.0$ & 3.5 \\
Bar supplement & 954 & 17.7 & 156 & - & 37 & 21 & - & 3.0 & 3.6 \\
& & & & & & & & & \\
Speargrass hay & 930 & 4.9 & 709 & 407 & - & - & - & 2.5 & 1.1 \\
Barley grain & 979 & 23.7 & 144 & 41 & 30 & 23 & 512 & $<1.0$ & 3.0 \\
Bar supplement & 971 & 23.2 & 146 & 45 & 33 & 24 & - & 3.8 & 3.1 \\
Molasses & 861 & 10.5 & - & - & - & - & - & 7.4 & 1.1 \\
MUP supplement & 869 & 25.3 & - & - & - & - & - & 3.3 & 2.0 \\
\hline
\end{tabular}


highest level of Bar supplement but the steer recovered quickly and returned to its previous grain intake. There were no clinical signs of molasses toxicity in steers of either age fed the MUP supplement.

\section{Liveweight change}

\section{Exp1}

In the absence of supplement the Control steers gained 0.11 (Young) and 0.17 (Old) kg/day. For supplement intakes expressed relative to liveweight (g DM/kg W.day), the growth responses of the two age groups of steers to different supplements are illustrated in Fig. 1 and the corresponding response relationships are shown in Table 2 . In this figure asymptotic curves replaced the corresponding quadratic curves, as they were deemed more biologically meaningful, except for that of Old steers receiving CSM supplement where the exponential curve was almost vertical at low intakes due to the absence of data points in the low intake range (0-2 g DM/kg W.day). For Young steers, the response trend with Bar was linear whereas with CSM it was curvilinear and $\mathrm{W}$ gains were much higher for steers offered CSM than steers offered Bar within the range of comparable intakes $(P<0.001$, compared at the quadratic level). With a supplement DM intake of $5 \mathrm{~g} / \mathrm{kg}$ W.day, the estimated growth rates of Young steers were 0.92 and $0.40 \mathrm{~kg}$ /day for CSM and Bar treatments, respectively. For the Old steers response relationships were curvilinear for both supplement types and again responses were higher for the CSM compared with the Bar treatment $(P<0.01)$, over the range of comparable intakes, although there was convergence of the curves at the upper intake level. With a supplement DM intake of $5 \mathrm{~g} / \mathrm{kg} \mathrm{W}$.day the estimated growth rates of Old steers were 1.15 and $0.91 \mathrm{~kg}$ / day for CSM and Bar treatments, respectively. Old steers outperformed their Young counterparts when both the CSM $(P<0.05)$ and Bar $(P<0.001)$ supplements were fed.

When supplement intakes were expressed in absolute terms ( $\mathrm{kg} \mathrm{DM} /$ day), the growth response curves were of similar degree of polynomial to those described above for intakes expressed on a $\mathrm{W}$ basis. However, within supplement type, there were no differences $(P>0.05)$ in response between age groups of steers when compared as quadratic functions and over a common range of supplement intakes. These trends are not illustrated but relevant relationships are described in Table 2.

Exp2

The linear and asymptotic representations of the growth response relationships to supplement intake are illustrated in Fig. 1 and corresponding equations are provided in Table 2. Without supplement, Young steers maintained weight $(0.02 \mathrm{~kg} /$ day) whereas Old steers lost $0.24 \mathrm{~kg} /$ day on the speargrass hay basal diet. When supplement intakes were expressed as a proportion of liveweight (g DM/kg W.day) the growth responses to supplement intake were best described by linear relationships for the Young steers and by curved functions for the Old steers (Fig. 1). For the Young steers the response to Bar was greater than to MUP $(P<0.01)$, growth rate increasing by 0.08 and 0.04 $\mathrm{kg}$ for each $\mathrm{g} \mathrm{DM} / \mathrm{kg} \mathrm{W}$ of each supplement fed, respectively. Similarly, with the Old steers, the response was greater $(P<0.05)$ for Bar than for MUP although to varying degrees as intake increased, as illustrated by the asymptotic curves in Fig. 1. For instance, when DM intake of each supplement was $5 \mathrm{~g} / \mathrm{kg} \mathrm{W}$.day the estimated growth rate difference was greater $(1.11 \mathrm{vs} 0.76 \mathrm{~kg}$ / day) than when DM intake was $10 \mathrm{~g} / \mathrm{kg} \mathrm{W.day} \mathrm{(1.33} \mathrm{vs} 1.11 \mathrm{~kg} /$ day), indicating some convergence of the response curves as supplement intakes increased. Within supplement type, the Old steers had higher growth responses than their Young counterparts for both Bar and MUP supplement treatments when compared as quadratic functions $(P<0.01)$. The trend was for greater convergence of response curves for Young and Old steers with Bar compared with MUP supplement.

Growth response relationships followed the same trends as above when supplement intakes were expressed in $\mathrm{kg} \mathrm{DM} /$ day (see Table 2), notably linear relationships for Young steers and curved relationships for Old steers, across supplement types. However, within supplement types differences between age groups were not significant for the MUP supplement $(P>0.05)$ but the response was still greater for Old compared with Young

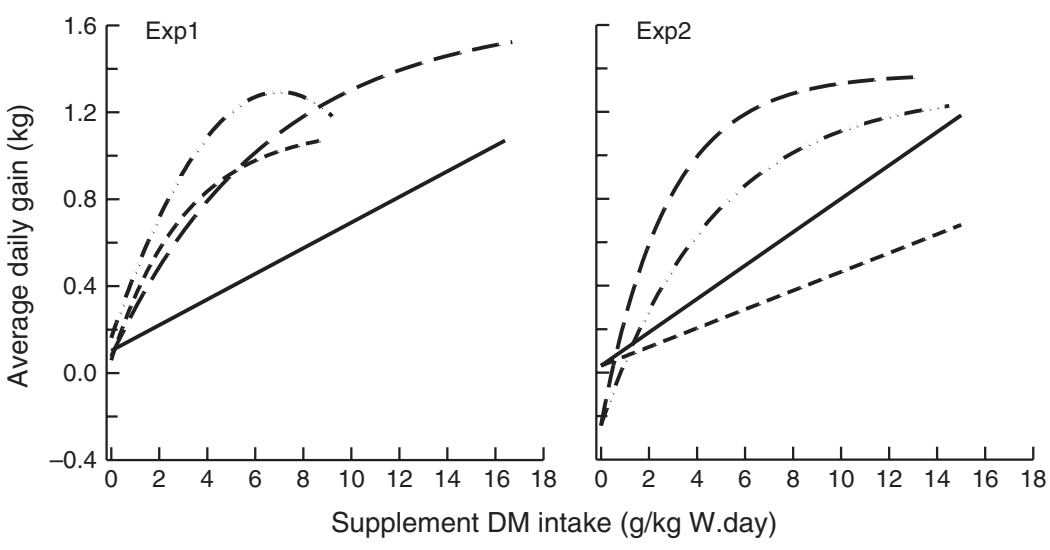

Fig. 1. Effects of intake of various supplements fed to steers of different ages in Exp1 (YoungBar, solid lines; Young-CSM, short-dash; Old-Bar, long-dash; Old-CSM, dash-dot-dot) and Exp2 (Young-Bar, solid; Young-MUP, short-dash; Old-Bar, long-dash; Old-MUP, dash-dot-dot) on the average daily gain of the steers. Treatments are described in the text and the equations describing the various relationships are given in Table 2. 
Table 2. Effect of age of steers (Age) and type and intake of supplement, expressed either as g DM/kg liveweight (W).day (XL) or kg DM/day (XK), on average daily gain, on hay and total dry matter (DM) intake, on dry matter digestibility (DMD) and on the concentrations of urea-nitrogen (urea-N) in plasma and of ammonia-nitrogen $\left(\mathrm{NH}_{3}-\mathrm{N}\right)$ in the rumen fluid, and the effect of estimated metabolisable energy intake (MEI, MJ/day; $\mathrm{MEIw}, \mathrm{kJ} / \mathrm{kg}$ $\mathrm{W}^{\mathbf{0 . 7 5}}$.day) on average daily gain and energy retention, for steers fed hay alone or with supplement in Experiments 1 and 2 (Exp1, Exp2)

Treatments included supplements based on a barley mix, Bar; cottonseed meal, CSM; and molasses/urea/protein meal mix, MUP; (see text for diet details). $P$-values are given for the linear (Lin.) and quadratic (Quad.) coefficients describing the relationships; ${ }^{*}, P<0.05$; ${ }^{* *}, P<0.01 ; * * *, P<0.001$; n.s., non-significant $(P>0.05)$; RSD, residual standard deviation; treatment differences are discussed in the text. Where the quadratic relationship was significant, and it was considered biologically appropriate, an asymptotic function has been fitted to the data as represented by the included equations. The significance levels for the linear and quadratic tests of curvature are still presented but the $R^{2}$ (adjusted) and RSD apply to the asymptotic relationships

\begin{tabular}{|c|c|c|c|c|c|c|c|}
\hline $\bar{Y}$ & Age & Supplement & Equation & $R^{2}$ & RSD & Lin. & Quad. \\
\hline & & & Exp1 & & & & \\
\hline \multirow{4}{*}{ Average daily gain (kg) } & Young & Bar & $\mathrm{Y}=0.103+0.059 \mathrm{XL}$ & 0.90 & 0.134 & $* * *$ & n.s. \\
\hline & & $\mathrm{CSM}$ & $\mathrm{Y}=1.136-1.077\left(0.726^{\mathrm{XL}}\right)$ & 0.94 & 0.112 & $* * *$ & $* *$ \\
\hline & Old & Bar & $\mathrm{Y}=1.649-1.572\left(0.860^{\mathrm{XL}}\right)$ & 0.97 & 0.105 & $* * *$ & $* *$ \\
\hline & & $\mathrm{CSM}$ & $\mathrm{Y}=0.162+0.324 \mathrm{XL}-0.023 \mathrm{XL}^{2}$ & 0.82 & 0.255 & $* * *$ & $* * *$ \\
\hline \multirow[t]{4}{*}{ Average daily gain (kg) } & Young & Bar & $\mathrm{Y}=0.0116+0.254 \mathrm{XK}$ & 0.90 & 0.132 & $* * *$ & n.s. \\
\hline & & CSM & $\mathrm{Y}=1.128-1.064\left(0.238^{\mathrm{XK}}\right)$ & 0.95 & 0.106 & $* * *$ & $* *$ \\
\hline & Old & Bar & $\mathrm{Y}=1.618-1.541\left(0.710^{\mathrm{XK}}\right)$ & 0.97 & 0.104 & $* * *$ & $* * *$ \\
\hline & & $\mathrm{CSM}$ & $\mathrm{Y}=0.168+0.676 \mathrm{XK}-0.1002 \mathrm{XK}^{2}$ & 0.81 & 0.258 & $* * *$ & $* * *$ \\
\hline \multirow{4}{*}{ Hay DM intake (g/kg W.day) } & Young & Bar & $\mathrm{Y}=27.91-11.69\left(0.817^{\mathrm{XL}}\right)-\mathrm{XL}$ & 0.71 & 1.690 & n.s. & $* *$ \\
\hline & & $\mathrm{CSM}$ & $\mathrm{Y}=27.10-10.88\left(0.730^{\mathrm{XL}}\right)-\mathrm{XL}$ & 0.48 & 1.742 & $*$ & $*$ \\
\hline & Old & Bar & $\mathrm{Y}=13.37-0.219 \mathrm{XL}$ & 0.36 & 1.891 & $* *$ & n.s. \\
\hline & & $\mathrm{CSM}$ & $\mathrm{Y}=23.14-10.99\left(0.635^{\mathrm{XL}}\right)-\mathrm{XL}$ & 0.63 & 1.700 & $* *$ & $* *$ \\
\hline \multirow[t]{4}{*}{ Total DM intake (g/kg W.day) } & Young & Bar & $\mathrm{Y}=27.91-11.69\left(0.817^{\mathrm{XL}}\right)$ & 0.91 & 1.561 & $* * *$ & $* *$ \\
\hline & & $\mathrm{CSM}$ & $\mathrm{Y}=27.10-10.88\left(0.730^{\mathrm{XL}}\right)$ & 0.87 & 1.669 & $* * *$ & $*$ \\
\hline & Old & Bar & $\mathrm{Y}=13.37+0.781 \mathrm{XL}$ & 0.90 & 1.891 & $* * *$ & n.s. \\
\hline & & $\mathrm{CSM}$ & $\mathrm{Y}=23.14-10.99\left(0.635^{\mathrm{XL}}\right)$ & 0.92 & 1.424 & $* * *$ & $* *$ \\
\hline \multirow[t]{4}{*}{$\operatorname{DMD}(\mathrm{g} / \mathrm{kg} \mathrm{DM})$} & Young & Bar & $\mathrm{Y}=549.3+8.10 \mathrm{XL}$ & 0.87 & 21.64 & $* * *$ & n.s. \\
\hline & & $\mathrm{CSM}$ & $\mathrm{Y}=589.3-47.72\left(0.0014^{\mathrm{XL}}\right)$ & 0.49 & 22.02 & $* *$ & $*$ \\
\hline & Old & Bar & $\mathrm{Y}=573.7+8.50 \mathrm{XL}$ & 0.95 & 13.14 & $* * *$ & n.s. \\
\hline & & $\mathrm{CSM}$ & $\mathrm{Y}=573.7+3.74 \mathrm{XL}$ & 0.49 & 15.66 & $*$ & n.s. \\
\hline \multirow[t]{4}{*}{ Rumen $\mathrm{NH}_{3}-\mathrm{N}$ conc. $(\mathrm{mg} / \mathrm{L})$} & Young & Bar & $\mathrm{Y}=1.28+5.59 \mathrm{XL}$ & 0.24 & 64.09 & $* *$ & n.s. \\
\hline & & $\mathrm{CSM}$ & $\mathrm{Y}=1.28+25.18 \mathrm{XL}$ & 0.87 & 34.35 & $* * *$ & n.s. \\
\hline & Old & Bar & $\mathrm{Y}=35.58+3.59 \mathrm{XL}$ & 0.25 & 41.02 & n.s. & n.s. \\
\hline & & $\mathrm{CSM}$ & $\mathrm{Y}=35.58+20.15 \mathrm{XL}$ & 0.91 & 25.99 & $* * *$ & n.s. \\
\hline \multirow[t]{4}{*}{ Plasma urea-N conc. $(\mathrm{mg} / \mathrm{dL})$} & Young & Bar & $\mathrm{Y}=2.772+0.112 \mathrm{XL}$ & 0.24 & 1.562 & n.s. & n.s. \\
\hline & & $\mathrm{CSM}$ & $\mathrm{Y}=2.772+1.874 \mathrm{XL}$ & 0.72 & 4.450 & $* * *$ & n.s. \\
\hline & Old & Bar & $\mathrm{Y}=4.674+0.380 \mathrm{XL}$ & 0.43 & 3.330 & $*$ & n.s. \\
\hline & & $\mathrm{CSM}$ & $\mathrm{Y}=4.674+2.941 \mathrm{XL}$ & 0.90 & 4.029 & $* * *$ & n.s. \\
\hline \multirow[t]{4}{*}{ Energy retention $\left(\mathrm{kJ} / \mathrm{kg} \mathrm{W}^{0.75} \text {.day }\right)^{\mathrm{A}}$} & Young & Bar & $\mathrm{Y}=-134.9+0.313$ MEIw & 0.89 & 32.26 & $* * *$ & n.s. \\
\hline & & CSM & $\mathrm{Y}=-207.0+0.469$ MEIw & 0.93 & 29.36 & $* * *$ & n.s. \\
\hline & Old & Bar & $\mathrm{Y}=-171.2+0.530 \mathrm{MEIw}-0.0002 \mathrm{MEIw}^{2}$ & 0.95 & 31.18 & $* * *$ & * \\
\hline & & $\mathrm{CSM}$ & $\mathrm{Y}=-187.5+0.691 \mathrm{MEIw}-0.0005 \mathrm{MEIw}^{2}$ & 0.94 & 28.51 & $* * *$ & * \\
\hline \multirow{5}{*}{ Average daily gain $(\mathrm{kg})$} & & & Exp2 & & & & \\
\hline & Young & Bar & $\mathrm{Y}=0.032+0.077 \mathrm{XL}$ & 0.93 & 0.122 & $* * *$ & n.s. \\
\hline & & MUP & $\mathrm{Y}=0.032+0.043 \mathrm{XL}$ & 0.81 & 0.140 & $* * *$ & n.s. \\
\hline & Old & Bar & $\mathrm{Y}=1.374-1.618\left(0.696^{\mathrm{XL}}\right)$ & 0.91 & 0.220 & $* * *$ & $* * *$ \\
\hline & & MUP & $\mathrm{Y}=1.302-1.545\left(0.811^{\mathrm{XL}}\right)$ & 0.82 & 0.273 & $* * *$ & $* * *$ \\
\hline \multirow[t]{4}{*}{ Average daily gain $(\mathrm{kg})$} & Young & Bar & $\mathrm{Y}=0.046+0.319 \mathrm{XK}$ & 0.92 & 0.133 & $* * *$ & n.s. \\
\hline & & MUP & $\mathrm{Y}=0.046+0.188 \mathrm{XK}$ & 0.83 & 0.132 & $* * *$ & n.s. \\
\hline & Old & Bar & $\mathrm{Y}=1.374-1.614\left(0.475^{\mathrm{XK}}\right)$ & 0.91 & 0.219 & $* * *$ & $* * *$ \\
\hline & & MUP & $\mathrm{Y}=1.320-1.560\left(0.654^{\mathrm{XK}}\right)$ & 0.84 & 0.262 & $* * *$ & $* * *$ \\
\hline \multirow[t]{4}{*}{ Average daily gain $(\mathrm{kg})^{\mathrm{A}}$} & Young & Bar & $\mathrm{Y}=0.63+0.030 \mathrm{MEI}$ & 0.95 & 0.104 & $* * *$ & n.s. \\
\hline & & MUP & $\mathrm{Y}=0.40+0.019 \mathrm{MEI}$ & 0.86 & 0.119 & $* * *$ & n.s. \\
\hline & Old & Bar & $\mathrm{Y}=0.88+0.022 \mathrm{MEI}$ & 0.93 & 0.208 & $* * *$ & n.s. \\
\hline & & MUP & $\mathrm{Y}=0.79+0.019 \mathrm{MEI}$ & 0.87 & 0.243 & $* * *$ & n.s. \\
\hline \multirow[t]{4}{*}{ Hay DM intake (g/kg W.day) } & Young & Bar & $\mathrm{Y}=25.47-11.13\left(0.861^{\mathrm{XL}}\right)-\mathrm{XL}$ & 0.57 & 2.102 & n.s. & $* *$ \\
\hline & & MUP & $\mathrm{Y}=14.24-0.202 \mathrm{XL}$ & 0.54 & 1.230 & $*$ & n.s. \\
\hline & Old & Bar & $\mathrm{Y}=21.41-9.01\left(0.479^{\mathrm{XL}}\right)-\mathrm{XL}$ & 0.86 & 1.146 & $* *$ & $* * *$ \\
\hline & & MUP & $\mathrm{Y}=13.20-0.209 \mathrm{XL}$ & 0.47 & 1.195 & $*$ & n.s. \\
\hline Total DM intake ( $\mathrm{g} / \mathrm{kg}$ W.day) & Young & Bar & $\mathrm{Y}=25.47-11.13\left(0.861^{\mathrm{XL}}\right)$ & 0.78 & 2.099 & $* * *$ & $* *$ \\
\hline
\end{tabular}


Table 2. (continued)

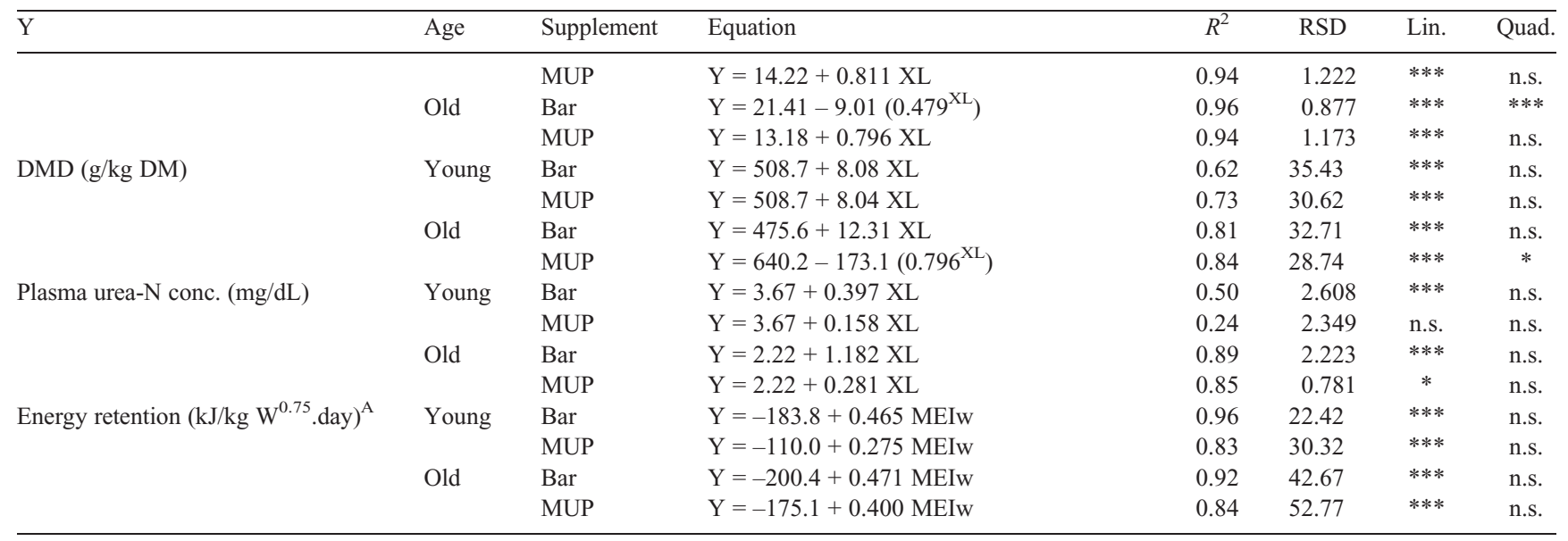

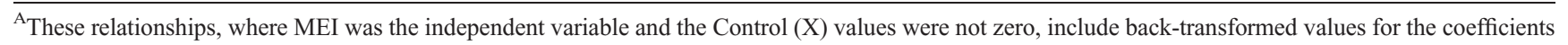
as the analyses were carried out on data after subtraction of the Control values.

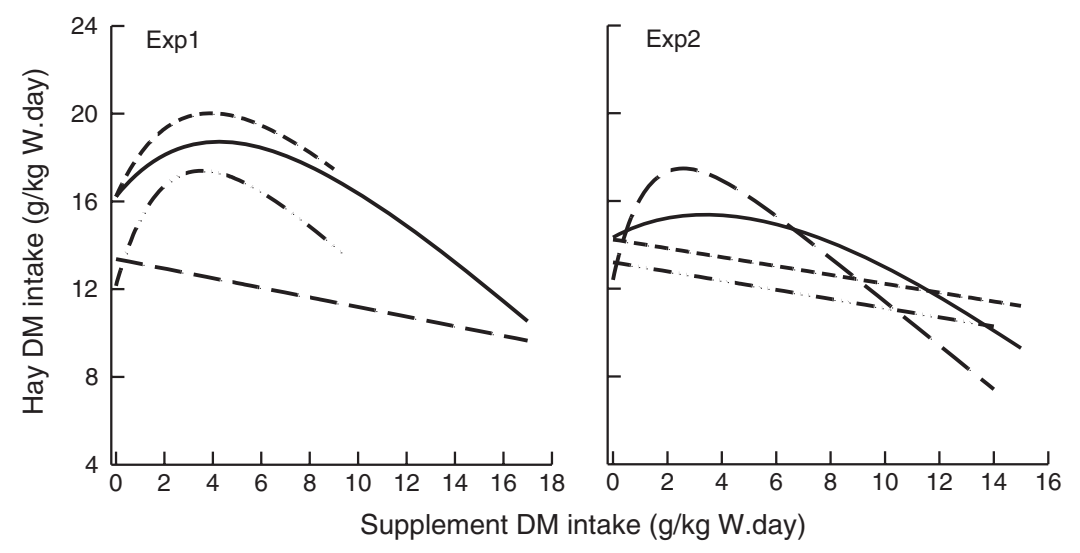

Fig. 2. Effects of intake of various supplements on hay DM intake of steers of different ages in Exp1 (Young-Bar, solid lines; Young-CSM, short-dash; Old-Bar, long-dash; Old-CSM, dashdot-dot) and Exp2 (Young-Bar, solid; Young-MUP, short-dash; Old-Bar, long-dash; Old-MUP, dash-dot-dot). Treatments are described in the text and the equations describing the various relationships are given in Table 2.

steers $(P<0.05)$, compared as quadratic functions, when the Bar supplement was fed.

\section{Intake and digestibility}

The effects of supplement type and intake, expressed relative to $\mathrm{W}$, on the intakes of hay and on DMD for both age groups of steers for both experiments are shown in Figs 2 and 3, respectively. The intakes of total DM, being the sum of hay and supplement intake, are not shown but the equations describing the relationships for both hay and total DM intake, and for DMD, with supplement DM intake are presented in Table 2.

\section{Exp1}

Without supplement, the predicted intake of pangola grass hay averaged $16.6 \mathrm{~g} \mathrm{DM} / \mathrm{kg} \mathrm{W.day} \mathrm{(3.72} \mathrm{kg} \mathrm{DM/day)} \mathrm{for} \mathrm{Young}$ steers and was $\sim 19 \%$ lower at $13.4 \mathrm{~g} \mathrm{DM} / \mathrm{kg} \mathrm{W}$.day $(5.91 \mathrm{~kg} \mathrm{DM} /$ day) for Old steers. With Young steers the effect of supplement on the intake of hay and total DM was curvilinear, with no difference between supplement types $(P>0.05)$, although this was over a much wider range of supplement intakes for Bar compared with CSM. Hay intake increased slightly at low supplement intakes for both supplement types but then declined at higher supplement intakes. Peak hay DM intakes of 18.7 and $20.0 \mathrm{~g} / \mathrm{kg} \mathrm{W}$.day occurred at Bar and CSM supplement intakes of 4.3 and $3.9 \mathrm{~g} \mathrm{DM} / \mathrm{kg} \mathrm{W}$.day, respectively. The curvilinear trend was repeated with Old steers receiving CSM where the peak hay DM intake was $17.4 \mathrm{~g} / \mathrm{kg} \mathrm{W}$.day achieved with CSM intake of $3.5 \mathrm{~g} \mathrm{DM} / \mathrm{kg} \mathrm{W}$.day. By contrast, Old steers fed the Bar supplement had a linear decline in hay intake across the full range of supplement intakes. Tested at the quadratic level, hay intake by Old steers was greater with CSM than with Bar over the range of comparable supplement intakes $(P<0.01$; 


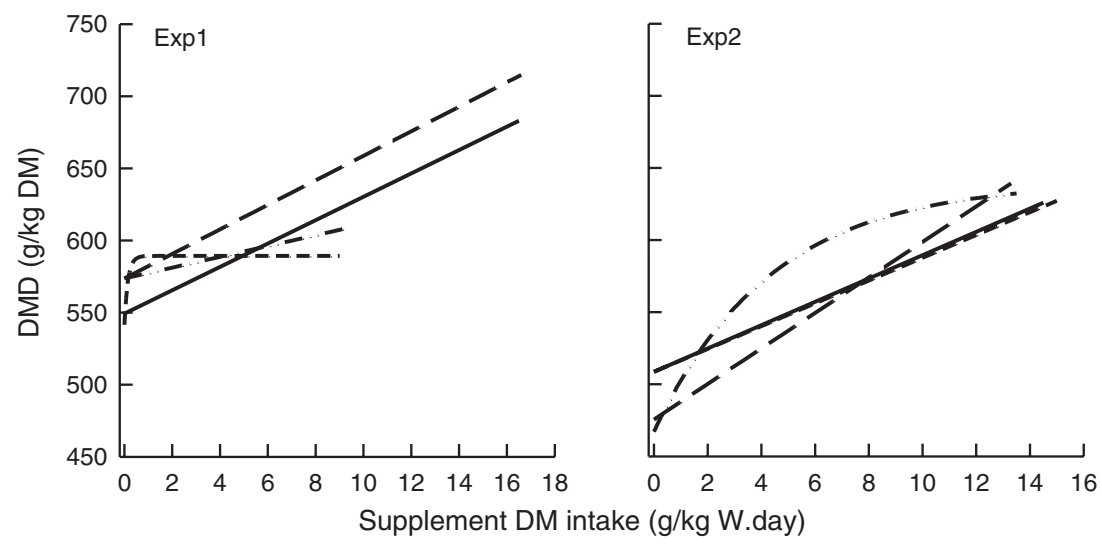

Fig. 3. Effects of intake of various supplements fed to steers of different ages in Exp1 (Young-Bar, solid lines; Young-CSM, short-dash; Old-Bar, long-dash; Old-CSM, dash-dot-dot) and Exp2 (Young-Bar, solid; Young-MUP, short-dash; Old-Bar, long-dash; Old-MUP, dash-dot-dot) on the digestibility of dry matter (DMD). Treatments are described in the text and the equations describing the various relationships are given in Table 2.

Fig. 2). Within supplement types, and when compared at the quadratic level, Young steers had higher hay intake (W-corrected) than their Old counterparts with both Bar and CSM treatments $(P<0.001)$. Total DM intakes followed similar trends to those described above for hay intake in terms of the degree of curvature (see Table 2) and in differences between steer age groups and supplement types.

The DMD of pangola grass hay fed to unsupplemented Young and Old steers averaged 549 and $574 \mathrm{~g} / \mathrm{kg} \mathrm{DM}$, respectively. The DMD increased linearly with increasing Bar supplement intake for both age groups of steers (see Fig. 3) so that when supplement intake was $15 \mathrm{~g} / \mathrm{kg} \mathrm{W}$.day, DMD was 671 and $701 \mathrm{~g} / \mathrm{kg}$ DM for Young and Old steers, respectively. The DMD also increased linearly with CSM supplement fed to Old steers and was $607 \mathrm{~g} / \mathrm{kg}$ DM when supplement DM intake was $9 \mathrm{~g} /$ $\mathrm{kg}$ W.day. The DMD response was curvilinear with increasing CSM intake by Young steers and has been represented as an exponential curve indicating a small increase in DMD at low intake of supplement but then no further increase as intake increased. For Old steers the rate of increase in DMD was greater to increasing supplement intake with Bar compared with CSM treatments $(P<0.01)$. Within supplement type, Old steers receiving Bar supplement had a consistently higher DMD (slopes not different $(P>0.05)$ but lines separate $(P<0.001)$ ) than their Young counterparts.

\section{Exp2}

The DM intakes of unsupplemented speargrass hay by Young and Old steers averaged $14.2 \mathrm{~g} / \mathrm{kg}$ W.day (3.12 kg/day) and $13.2 \mathrm{~g} / \mathrm{kg} \mathrm{W}$.day $(5.40 \mathrm{~kg} /$ day $)$, respectively. For both age groups of steers hay intake, expressed as a proportion of $\mathrm{W}$, changed in a curvilinear fashion with the Bar supplement such that there was a small increase at low levels of feeding followed by a decline at higher levels of supplement intake (Fig. 2). The rate of decline in hay intake was greater for Old compared with Young steers fed the Bar supplement $(P<0.05)$. Peak hay DM intakes of 15.4 and $17.5 \mathrm{~g} / \mathrm{kg} \mathrm{W}$.day were achieved with the Bar supplement by Young and Old steers when supplement DM intakes were 3.4 and $2.6 \mathrm{~g} / \mathrm{kg} \mathrm{W}$.day, respectively. By contrast, hay intake by both age groups of steers declined linearly over the full range of intakes of MUP supplement with the rate of decline similar $(P>0.05)$ for both. Comparisons made at the quadratic level indicated that there were differences in hay intake with the two supplement types when fed to Old steers $(P<0.05)$, which varied according to supplement intake (see Fig. 2). This trend was similar for the Young steers $(P=0.06)$.

Trends and statistical differences were similar for total intakes to those described above for hay intakes with curvilinear responses to the Bar supplement for both age groups of steers (Table 2). The total intake responses were linear with MUP supplementation of both age groups of steers, with no difference in the rate of increase in total intake (slope) for the two groups $(P>0.05)$.

The DMD of the unsupplemented speargrass hay averaged 509 and $476 \mathrm{~g} / \mathrm{kg}$ DM for Young and Old steers, respectively, and increased linearly with increasing intake of supplement for all combinations of steer age group and supplement type except with Old steers fed the MUP mix, where DMD increased quadratically (Table 2; Fig. 3). When the supplement DM intake was $15 \mathrm{~g} / \mathrm{kg}$ W.day, the DMD reached $629 \mathrm{~g} / \mathrm{kg}$ DM for Young steers receiving both supplements and $660 \mathrm{~g} / \mathrm{kg}$ DM for Old steers receiving the Bar supplement. Differences between supplement types were not significant for the Young steers and, when compared as quadratic functions, were also not different for the Old steers. Within supplement type there were no differences between steer age groups in the DMD response $(P>0.05)$.

\section{Rumen and blood metabolites}

\section{Exp1}

The equations relating the effects of supplement intake, averaged over the total feeding period, on concentrations of various metabolites are shown in Table 2. Relationships were also examined using the supplement intake determined for the $3 \mathrm{~h}$ before sampling but the trends were not different from those averaged on a daily basis over the experimental period. The 
concentration of $\mathrm{NH}_{3}-\mathrm{N}$ in rumen fluid after feeding was very low for the unsupplemented Young steers $(<2 \mathrm{mg} / \mathrm{L})$ but higher for the corresponding Old steers $(36 \mathrm{mg} / \mathrm{L})$. The effect of the inclusion of Bar supplement (including urea-S) in the diet was a gradual linear increase in $\mathrm{NH}_{3}-\mathrm{N}$ concentration for both age groups of steers, significant for the Young $(P<0.01)$ but only a trend for the Old steers $(P=0.07)$, reaching peak values of 91 and $93 \mathrm{mg} / \mathrm{L}$, respectively, when Bar supplement intake approached peak level at $\sim 16 \mathrm{~g} \mathrm{DM} / \mathrm{kg}$ W.day (Fig. 4). By contrast, CSM supplementation elicited a steep linear increase in $\mathrm{NH}_{3}-\mathrm{N}$ concentration with both steer age groups, which were much higher than for their Bar-fed counterparts $(P<0.001$ for both age groups; see Fig. 4), reaching 228 and $217 \mathrm{mg} / \mathrm{L}$, respectively, when CSM supplement DM intake peaked at $\sim 9 \mathrm{~g} /$ $\mathrm{kg}$ W.day. There were no differences between steer age groups for either supplement type $(P>0.05)$. The trends were similar for PUN, with shallow linear increases in concentration for the Bar treatments, significant for Old $(P<0.05)$ but not Young

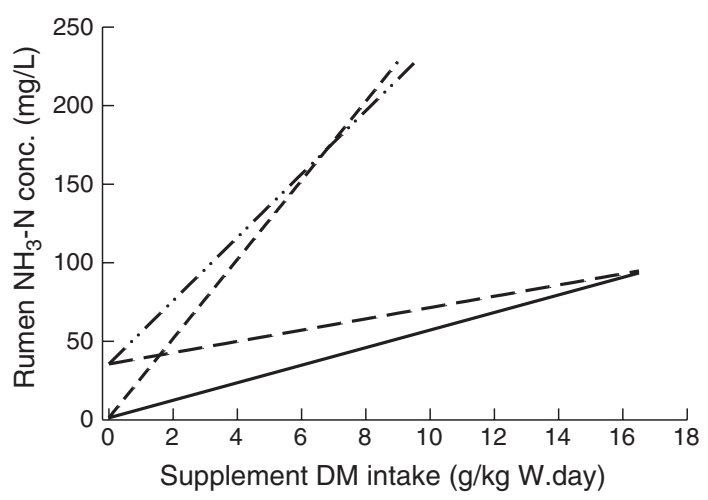

Fig. 4. Effects of intake of various supplements fed to steers of different ages in Exp1 (Young-Bar, solid lines; Young-CSM, short-dash; Old-Bar, long-dash; Old-CSM, dash-dot-dot) on the concentration of ammonianitrogen $\left(\mathrm{NH}_{3}-\mathrm{N}\right)$ in rumen fluid $3 \mathrm{~h}$ after feeding the hay, urea-S and CSM and $2 \mathrm{~h}$ after feeding the Bar mix. Treatments are described in the text and the equations describing the various relationships are given in Table 2. steers, and steep increases with increasing CSM intake across steer ages (see Fig. 5, Table 2). Across age groups the rates of increase were greater for CSM than with Bar treatments ( $P<0.001$ for both age groups). Within supplement types, PUN concentration increased more steeply in Old compared with Young steers $(P<0.01)$ for both supplement types.

Exp2

Urea-N concentration in plasma averaged 3.7 and $2.2 \mathrm{mg} /$ $\mathrm{dL}$ for unsupplemented Young and Old steers, respectively. Concentrations were not increased significantly by MUP supplement in Young steers but increased linearly with Bar in Young and with both supplement types in Old steers (Fig. 3, Table 2). The increase in PUN concentration with supplement intake was greater with Bar compared with MUP in Old steers $(P<0.001)$ and was also greater in Old compared with Young steers given the Bar supplement $(P<0.001)$.

\section{Energy retention}

\section{Exp1}

With Young steers, ER increased linearly with ME intake (W basis) for both supplement types but the slope of the trend line was greater for CSM compared with Bar treatments $(P<0.001$; see Fig. 6). The corresponding trends for Old steers were curvilinear and were not different $(P>0.05)$ between supplement types. Within supplement types, compared at the quadratic level, there was no difference between age groups of steers given the CSM supplement but with Bar supplement the response was greater for Old compared with Young steers $(P<0.05)$. The estimated maintenance requirements (zero ER) for the Young and Old steers averaged 437 and $414 \mathrm{~kJ} / \mathrm{kg} \mathrm{W}^{0.75}$. day, respectively.

\section{Exp2}

Estimated ER increased linearly with ME intake for each steer age group $\times$ supplement type combination (Fig. 6; Table 2).

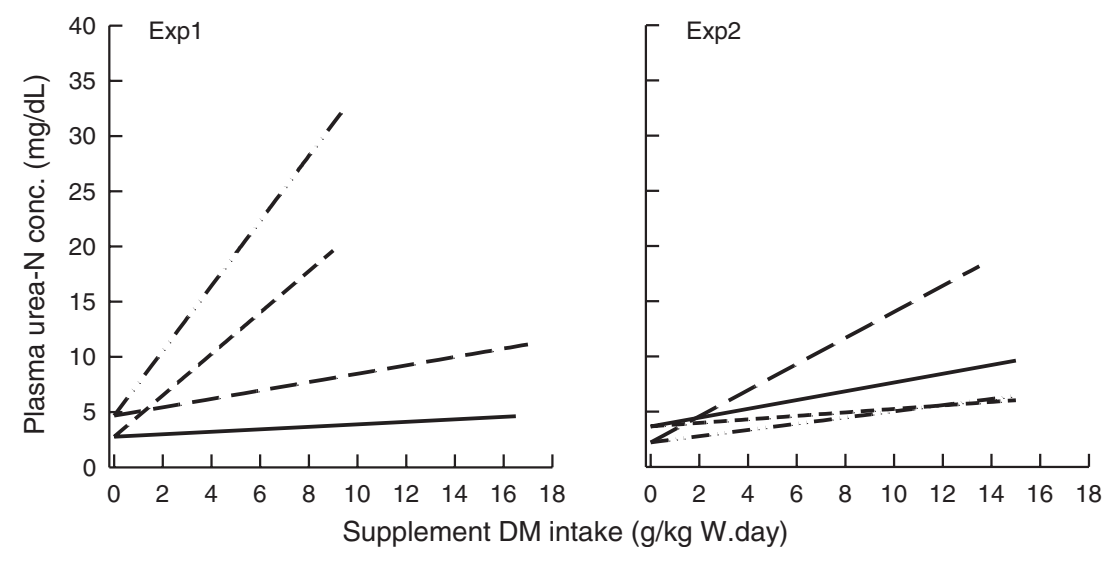

Fig. 5. Effects of intake of various supplements fed to steers of different ages in Exp1 (Young-Bar, solid lines; Young-CSM, short-dash; Old-Bar, long-dash; Old-CSM, dash-dot-dot) and Exp2 (Young-Bar, solid; Young-MUP, short-dash; Old-Bar, long-dash; Old-MUP, dash-dot-dot) on the concentration of urea-nitrogen in blood plasma. Treatments are described in the text and the equations describing the various relationships are given in Table 2. 


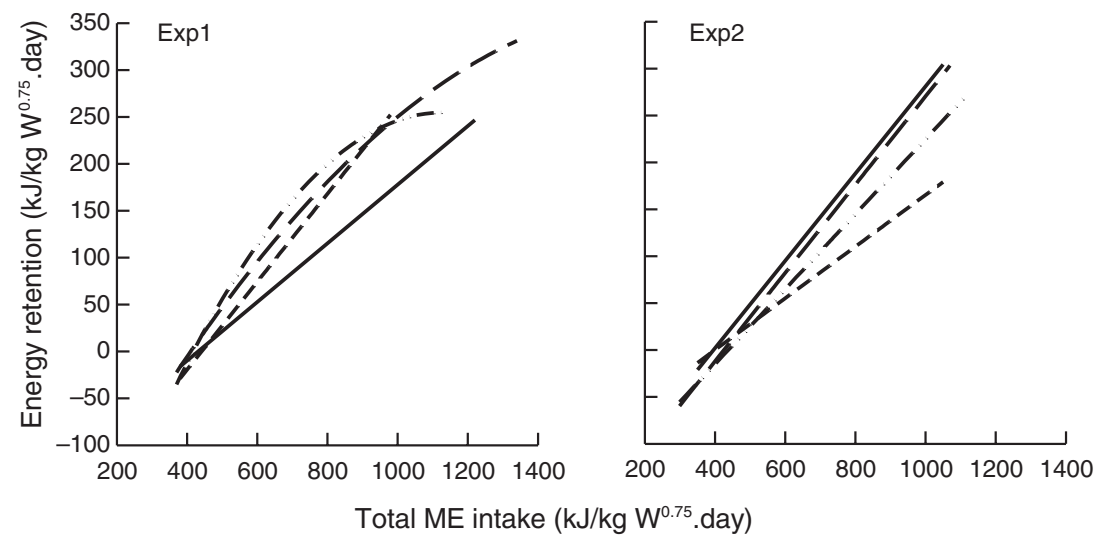

Fig. 6. Effects of estimated intake of metabolisable energy on the estimated energy retention of steers of different age groups in Exp1 (Young-Bar, solid lines; Young-CSM, short-dash; Old-Bar, long-dash; Old-CSM, dash-dot-dot) and Exp2 (Young-Bar, solid; Young-MUP, short-dash; Old-Bar, long-dash; Old-MUP, dash-dot-dot). Treatments are described in the text and the equations describing the various relationships are given in Table 2.

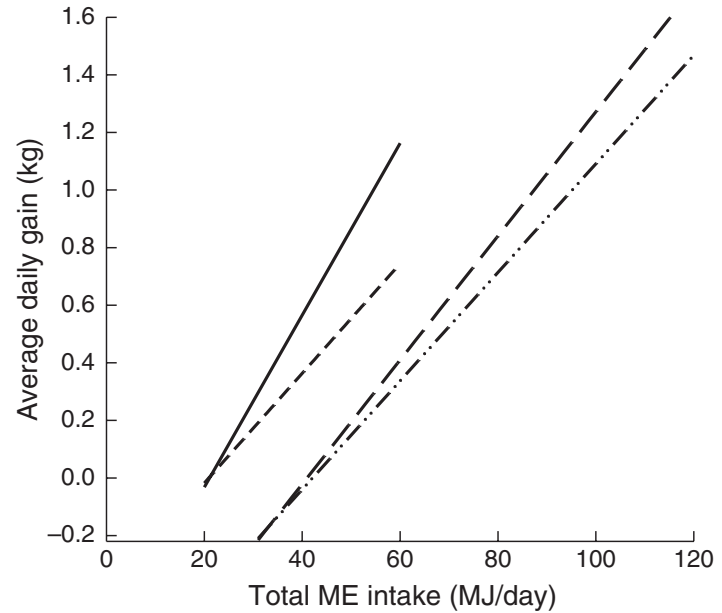

Fig. 7. Effects of estimated intake of metabolisable energy on the average daily gain of steers of different age groups in Exp2 (Young-Bar, solid lines; Young-MUP, short-dash; Old-Bar, long-dash; Old-MUP, dash-dot-dot). Treatments are described in the text and the equations describing the various relationships are given in Table 2.

The rate of increase was greater with Bar compared with MUP supplementation for both Young $(P<0.001)$ and Old $(P<0.05)$ steers. Within supplement type, there was no difference in the trend lines for the two steer age groups fed the MUP supplement $(P>0.05)$ but with the Bar supplement the regression lines were separate for the two age groups $(P<0.05)$ but had similar slopes $(P>0.05$; see Fig. 6). Based on these relationships, the estimated maintenance requirements for the Young and Old steers averaged 397 and $432 \mathrm{~kJ} / \mathrm{kg} \mathrm{W}^{0.75}$.day, respectively.

The differences in energy requirements for maintenance and growth for steers of different ages were also demonstrated in Fig. 7 where growth rate was plotted against absolute ME intake $(\mathrm{MJ} /$ day). With the Bar treatments, the regression lines for Young and Old were separate $(P<0.001)$ and the slopes were different
$(P=0.047)$ whereas with the MUP treatments the regression lines for the two age groups were effectively parallel $(P>0.05)$ and trending towards separation $(P=0.056)$. There was a $20.6 \mathrm{MJ} /$ day difference in the energy requirements for maintenance (zero average daily gain) between Young and Old steers (21 and $41.6 \mathrm{MJ} /$ day, respectively).

\section{Discussion}

These experiments were conducted to compare the responses by steers at different stages of maturity to varying types and intakes of supplement in an effort to provide practical information on the optimum timing and type of nutritional inputs within the growth path of cattle in the seasonally dry tropics of Australia. Bos indicus crossbred steers typical of those predominating throughout northern Australia, and tropical forages similar in quality to those commonly grazed during the dry season in this region, were used. For instance, the pangola grass hay used in Exp1 was only of sufficient quality to maintain $\mathrm{W}$ of both age groups of steers whereas, with the speargrass hay used in Exp2, Young steers only maintained $\mathrm{W}$ whereas Old steers sustained small $\mathrm{W}$ losses. Any potentially confounding effects of genotype of the cattle were removed by sourcing steers of both ages from the same herd.

\section{Intake}

The higher intakes of hay (W-corrected) by unsupplemented Young compared with Old steers are consistent with theoretical predictions. Intakes predicted with NRDR (2007; table 6.4) for steers selecting a diet of 50\% DMD were $46 \%$ higher for $200-\mathrm{kg}$ than for $450-\mathrm{kg}$ steers whereas in our study unsupplemented Young steers consumed $24 \%$ and $8 \%$ more hay than Old steers in Exp1 (pangola grass hay; DMD 549-574 $\mathrm{g} / \mathrm{kg} \mathrm{DM}$ ) and Exp2 (speargrass hay; DMD 476-509 g/kg DM), respectively. This between-experiment difference in the magnitude of the intake advantage to Young steers stemmed primarily from the reduced intake of Young steers in Exp2 compared with Exp1 (14.2 vs $16.6 \mathrm{~g} \mathrm{DM} / \mathrm{kg} \mathrm{W}$. 
day), as DM intakes were similar for Old steers in both experiments (13.2 vs $13.4 \mathrm{~g} / \mathrm{kg}$ W.day). The lower $\mathrm{N}$ content of speargrass hay relative to pangola grass hay $(4.9 \mathrm{vs} 6.7 \mathrm{~g} / \mathrm{kg}$ $\mathrm{DM}$ ) is a possible contributing factor as young ruminants are highly sensitive to protein supply for lean growth (Ørskov 1970). However, the growth responses to CSM discussed below suggest that the Old steers also had a high demand for protein, although it is possible that the balance in requirements for rumen-degradable (RDP) and undegraded dietary protein varied between age classes of steers.

Supplements had variable effects on intake of the hay component of the diet. The associative effects observed between supplement and forage intake have been reviewed previously (e.g. Chase and Hibberd 1987; Schiere and de Wit 1995; Dixon and Stockdale 1999; Moore et al. 1999), including in our previous paper in this series (McLennan et al. 2017) to which the reader is referred for more detailed discussion. In relation to the Young steers, the current design mimicked that of McLennan et al. (2017) who used similar steers (156-165-kg W) and supplements, including CSM and 'energy sources' comparable to the Bar and MUP mixes of the present experiments, yet in the present studies we did not reproduce the linear depression in hay intake they reported with increasing supplement intake (up to $\sim 18 \mathrm{~g} \mathrm{DM} / \mathrm{kg}$ W.day), except with the MUP treatment. Instead, with both the CSM and Bar supplements, hay intake by Young steers responded in a curvilinear fashion so that there was initially a small increase followed by a reduction in hay intake as supplement intake increased (see Fig. 2).

A possible explanation for these discrepancies lies in the difference in protein content of the basal forages used, as suggested by McCollum and Horn (1990) and Owens et al. (1991). Although McLennan et al. (2017) also used lowquality tropical hay (Rhodes grass; Chloris gayana) it had higher $\mathrm{N}$ content than the forages used in the present studies (10 vs 4.9-6.7 g/kg DM), a difference, although small, perhaps sufficient to provide the disparities in intake response recorded with the CSM and Bar-type supplements, attributable to dietary$\mathrm{N}$ adequacy. In support, when graded levels of casein were infused into the rumen of cattle fed low-quality forage, forage consumption changed in a quadratic fashion, initially increasing and then declining (Köster et al. 1996; Klevesahl et al. 2003; Wickersham et al. 2004). Other studies (Perdok and Leng 1990; Dolberg and Finlayson 1995) have supported the linear decline in intake reported by McLennan et al. (2017). The threshold protein content in forage for a stimulus in forage intake with protein supplementation is not clear but where it has occurred it suggests an initial correction of a ruminal-N deficiency.

Differences in the supplement feeding protocols may also have contributed to these variances in hay response by Young steers. McLennan et al. (2017) fed CSM over a range of 0-20, in steps of $5, \mathrm{~g} / \mathrm{kg} \mathrm{W}$.day (as fed) compared with the current range of $0-10$ in steps of $2.5 \mathrm{~g} / \mathrm{kg}$ W.day. Having additional data points at smaller increments, as in Exp1, would have better enabled the definition of a quadratic response curve especially as the growth data indicated that the highest incremental growth responses occurred at low CSM intakes. However, the Bar supplement was fed over a wider intake range of 0-20, incrementing by $5, \mathrm{~g} / \mathrm{kg} \mathrm{W.day} \mathrm{(as} \mathrm{fed)} \mathrm{in} \mathrm{both} \mathrm{Exp1} \mathrm{and}$
Exp2, similar to the approach of McLennan et al. (2017). The difference with this supplement though may lie in the method of providing urea to the steers and in their eventual intake of the RDN source. In both studies urea was included in the grain- and molasses-based rations in quantities theoretically sufficient to provide RDN for fermentation of both the forage and supplement components of the diet. However, in the current experiments it was fed mixed with the hay whereas McLennan et al. (2017) included it in the grain mix, so it is possible that differences in total $\mathrm{N}$ supply and in the synchrony of supply of RDN and fermentable energy (Sinclair et al. 1995), coupled with the differences in forage $\mathrm{N}$ content discussed above, contributed to the observed differences in these effects of supplement on hay intake.

A similar argument could be used to explain the difference in forage intake response between Bar and MUP treatments in Exp2. The urea was included in the MUP mix for the MUP treatments, not on the hay as for the Bar treatments, as on previous experience grain was consumed much more quickly than molasses in pens leading to risks of urea toxicity. As proposed above, these urea feeding anomalies possibly resulted in different rates of availability of degradable- $\mathrm{N}$ in the rumen and variation in the synchrony of this $\mathrm{N}$ with fermentable energy from the hay and supplement sources, as supported by the lower concentrations of urea-N in the plasma with MUP compared with Bar treatments.

We found no other published reports comparing the associative intake effects for cattle of different ages. In our experiments, the forage intake trends described above for Young steers were repeated with Old steers with one exception; there was a linear reduction in forage intake with the feeding of the Bar supplement to Old steers in Exp2 contrasting with the curvilinear response in Exp1 (see Fig. 2). The reasons for this finding are not obvious. The speargrass hay in Exp2 was of slightly lower crude protein content than the pangola grass hay used in Exp1 so an initial increase in hay intake to the provision of additional RDN should have been more likely in Exp2 than in Exp1 (Owens et al. 1991). However, the steeper linear increase in plasma urea-N concentration with Bar in Exp 2 compared with Exp1 suggests a lower uptake of the RDN in the rumen and thus lower utilisation rate, with implications for a greater reduction in forage intake.

\section{Growth rate}

Considering the Young steers alone, the growth responses to all supplement types in both experiments were generally consistent with those reported in the earlier paper of this series (McLennan et al. 2017) where steers of comparable age and W were fed similar low-quality tropical grass hay. With supplement intake expressed relative to $\mathrm{W}$, these parallels included the linear responses to increasing inclusion of the energy sources in the form of Bar or MUP mixes, the higher response with Bar compared with MUP supplements despite the inclusion in the current study, but not the previous one, of a small amount of protein meal ( $\sim 8 \%$ by weight) in the molasses, and the curvilinear growth response to the CSM supplement. For more detailed discussion of these trends the reader is referred to the previous paper (McLennan et al. 2017). 
Based on the response relationships to both protein meals and energy sources in this previous study, the authors concluded that protein was the primary deficiency for young cattle given low-quality tropical forages, and that substantial improvements in growth performance would result from provision of small amounts of a protein source of medium to high rumen degradability. The much higher growth response to CSM than to Bar supplement at low intake (0-5 g DM/kg W.day) by Young steers in Exp1 supports this assertion albeit that it is conceded that both supplement types provide the animal with both protein and energy, but in different proportions. Assuming a rumen degradability of protein of 0.87 for pangola grass (Bowen 2003), the calculated ratio of RDP : digestible DM (DDM) for unsupplemented Young steers in Exp1 was $\sim 66 \mathrm{~g} / \mathrm{kg}$, providing therefore considerable scope for a response to a rumendegradable source of protein before the proposed optimal ratio of 130-170 g RDP/kg DOM (AFRC 1993; NRDR 2007) for microbial protein synthesis was exceeded. With assumptions for protein degradabilities of barley and CSM of 0.86 and 0.71 (AFRC 1993), respectively, and assuming that 0.8 of the urea fed on hay in the Bar treatments was consumed (allowing for $20 \%$ hay refusal daily) and that it was used in the rumen with 0.8 efficiency, the calculated RDP/DDM for the Bar treatments in Exp1 were 108, 112, 119 and $133 \mathrm{~g} / \mathrm{kg}$ for diets including 5, 10, 15 and $20 \mathrm{~g} \mathrm{DM} / \mathrm{kg} \mathrm{W.day} \mathrm{of} \mathrm{supplement,} \mathrm{respectively.} \mathrm{Thus,}$ even allowing for the conversion of DDM to DOM, it appears that there was a deficiency of RDP in the Bar-based rations except at the highest level of supplementation despite the inclusion of urea to provide RDN for fermentation of both the hay and supplement in the rumen (see discussion above). The corresponding estimate for RDP/DDM when CSM was fed at just $5 \mathrm{~g} \mathrm{DM} / \mathrm{kg} \mathrm{W}$.day was $168 \mathrm{~g} / \mathrm{kg}$. Of practical significance is the finding that providing CSM to the Young steers at just $7 \mathrm{~g}$ $\mathrm{DM} / \mathrm{kg} \mathrm{W}$.day, or $\sim 1.4 \mathrm{~kg} \mathrm{DM} /$ day for a $200-\mathrm{kg}$ steer, increased growth rate from around maintenance to over $1 \mathrm{~kg} / \mathrm{day}$. The same response with the Bar mix required a much higher DM intake of $\sim 16 \mathrm{~g} / \mathrm{kg} \mathrm{W}$.day, or $3.2 \mathrm{~kg} /$ day.

Perhaps the most unexpected findings from the present study were that, when the effects of the differences in $\mathrm{W}$ of the two steer groups were accounted for by expressing supplement intake as a proportion of $\mathrm{W}$, the growth response trends to various supplement types with Old steers ranked in similar order to, but were greater than, those of corresponding treatments for their Young counterparts. This observation included the higher response to CSM relative to Bar supplement in the Old steers. One noticeable difference though was in the shape of the fitted response relationships, being curvilinear for all supplement types for Old steers compared with the linear responses to Bar and MUP supplements with the Young steers. This could reflect the fact that growth rates of Old steers were approaching an upper gain threshold for that class of cattle on those diets which, irrespective of supplement type or intake, still included a substantial component of low-quality tropical forage. Although the difference between responses to CSM and Bar supplements tended to be less with Old compared with Young steers over the range of comparable intakes it still suggests that RDP could be a major deficiency for these older steers consuming a low-quality tropical forage, supported by the fact that the calculated RDP/ DDM for Old steers in Exp1 offered diets with Bar supplements fed at 5, 10, 15 and $20 \mathrm{~g} / \mathrm{kg} \mathrm{W}$.day were 117, 119, 123 and $131 \mathrm{~g} /$ $\mathrm{kg}$, respectively, and for the CSM fed at just $5 \mathrm{~g} / \mathrm{kg} \mathrm{W}$.day, was $179 \mathrm{~g} / \mathrm{kg}$. These calculations do not account for recycling of urea to the rumen but the relative differences between supplements will likely apply nevertheless.

Fitting an asymptotic function to the growth data for Old steers receiving CSM resulted in an aberrant response curve suggesting an almost vertical response phase at low intake of supplement. Although such a response curve is illogical, it is nonetheless a feature of the data recorded where there was a very abrupt response to an even small increment of CSM (i.e. $2 \mathrm{~g} / \mathrm{kg} \mathrm{W}$. day) and little apparent increase in response thereafter. The fitted quadratic curve shown in Fig. 1 could also be considered aberrant in that it portrays a declining response as supplement intake increases, also without logical justification.

In theory, the requirements of, and responses by, steers separated in age by 2 years to provision of supplements rich in protein and energy should be quite different. At trial commencement $\mathrm{W}$ of 200 and $430 \mathrm{~kg}$, the Young and Old steers had relative sizes of 0.33 and 0.72 , respectively, where relative size is the $\mathrm{W}$ expressed as a proportion of the standard reference weight (NRDR 2007) of the steer, here assumed to be $600 \mathrm{~kg}$. As cattle age, the proportional deposition of different tissue types changes, with relatively more protein and less fat deposited in young compared with older cattle, and vice versa (NRC 1996; NRDR 2007). For instance, calculations based on NRDR (2007) indicate that, for Bos indicus steers weighing either 200 or $430 \mathrm{~kg}$ and growing at $1 \mathrm{~kg} /$ day the composition of empty bodyweight gain would be 300 and $570 \mathrm{~g} / \mathrm{kg}$ fat and 154 and $90 \mathrm{~g} / \mathrm{kg}$ protein, respectively. Furthermore, the rate of skeletal growth declines as animals approach maturity. These trends should be reflected in the type of nutrients required and the energy cost of providing them. In short, older cattle in the fattening phase require glucogenic precursors to support fat synthesis (MacRae and Lobley 1982), as perhaps provided by starch in grains or glucogenic amino acids in MP, whereas younger cattle have a high demand for protein for lean growth (Ørskov 1970). The energy cost for protein deposition is markedly higher than for fat (MacRae and Lobley 1982; Butler-Hogg and Cruickshank 1989; Poppi 1990), largely related to the higher, energy-demanding turnover of protein relative to fat (MacRae and Lobley 1982). However, energy used solely for protein synthesis results in 5-6 times greater empty $\mathrm{W}$ gain than when it is used solely for fat deposition, largely due to the association of water with lean tissue deposition (NRDR 2007).

Our results only partially affirmed these theoretical differences in the nutritional requirements of the different age groups of steers. They did not support the assertion that young steers would grow faster than their older counterparts due to the different composition of gain, favouring higher protein deposition in young animals. Both age groups were highly responsive to provision of a high-protein source, greater than the corresponding responses to Bar supplement, indicating the needs of both groups for additional MP for growth. The higher response to CSM by Old compared with Young steers (Fig. 1) was most evident at low intakes of supplement, suggesting that a deficiency in MP supply still applied for Young steers at these low intakes and/or that the MP requirements of Old steers were 
met with lower inputs of protein meal than for Young steers. Furthermore, the smaller gap between response curves to CSM and Bar treatments for Old compared with Young steers in Exp1 could be interpreted as Young steers being unable to grow as fast as mature steers in response to additional supplemental energy when MP was deficient, as supported by the lower responses of Young steers to both Bar and MUP supplements at low to medium intakes in Exp2 compared with their older counterparts (Fig. 1). Alternatively, or in addition, it could reflect the greater need of mature steers for a high glucogenic diet, as suggested above. In conclusion, our results seem equivocal in their support for the accepted hypothesis of the dietary influence on growth and body compositional changes in steers at different stages of maturity.

In practice, the important economic consideration when formulating supplements for grazing cattle is the growth response achieved relative to the amount and cost of additional nutrients provided. In this respect, it was significant that when supplement intakes were expressed in absolute terms (kg DM/ day), rather than as $\mathrm{W}$-corrected intakes, the growth responses per unit supplement intake were comparable for Young and Old steers for most supplement types and intakes tested in the present experiments. The only difference was a slightly higher response to Bar supplement in Old compared with Young steers in Exp1. This implies a similar conversion rate of nutrients to additional growth $(\mathrm{kg} / \mathrm{kg})$ for both age groups of steers despite their difference in W. However, it is important to note that for any level of supplement intake the Old steers consumed considerably more forage than their Young counterparts in absolute terms ( $\mathrm{kg} \mathrm{DM} /$ day), albeit that their intakes were lower on a W-corrected basis (Fig. 2). Thus, the proportion of supplement in the total diet was always lower for Old compared with Young steers at any given supplement intake.

Part of the explanation for the perceived failure of our results to support the theoretical differences in nutrient requirements and responses of cattle at different stages of maturity could lie in consideration of their position on the theoretical sigmoidal growth curve, as described for instance by Brody (1945). Although the Young steers would belong on that phase of the growth curve defined as accelerating (slope), before the point of inflection, the Old steers, which we observed were only in the mid-range of body condition (score 2-3 on a 5-point scale) at the start of feeding, would belong on the decelerating but still reasonably steep part of the curve, well short of the limiting stage where growth rate approaches zero at maturity. Accordingly, steers at both stages of maturity would have considerable potential for growth and accretion of both muscle and fat, albeit in different proportions, although skeletal growth would have been much reduced in the Old steers compared with their Young counterparts (Berg and Butterfield 1968). Based on their experimental entry $\mathrm{W}$, the Old steers had not yet reached mature frame size, providing scope for further skeletal growth and associated muscle accretion (Always et al. 1990) in addition to fat deposition. Thus in this respect the comparison was probably not of one age group depositing mainly lean tissue and the other fat, but of two groups with varying capacity for both. On this basis the difference in requirements for nutrients of the two age groups would not be as extreme as initially expected.

\section{Energy intake and retention}

Although $\mathrm{W}$ changes provide the most practical method of comparing supplement responses, their interpretation is confounded by the variable associative effects between the supplement and the basal diet, as described above. Instead, comparing treatments on an energetic basis, as illustrated in Fig. 6, incorporates these variable effects of dietary components and allows a more theoretical examination of treatment effects. Some caution though is required as both ER and ME intake are estimated from established equations (NRDR 2007). The results from Exp1 demonstrate higher efficiency of use of energy with CSM than with Bar supplement by Young steers supporting the above proposition that these immature steers have a high requirement for MP for muscle deposition. The respective slopes of the regression lines for CSM and Bar treatments were 0.47 and 0.31 , which could be considered 'virtual' $\mathrm{k}_{\mathrm{g}}$ values representing the efficiency with which the steers used the total ME intake for gain. However, they are not true $\mathrm{k}_{\mathrm{g}}$ values as the proportion of supplement and hay varied with intake of supplement, as therefore also did the M/D of the diet. In contrast to this linear relationship, the corresponding one with CSM fed to young steers in our previous study (McLennan et al. 2017) was curvilinear, reducing in slope as intakes increased, but in that experiment the range in supplement intakes was double that of the present one.

The similar energetic response of Old and Young steers fed CSM in Exp1 could suggest an analogous high requirement for MP by the more mature steers but the lack of difference in energy efficiency with Bar by these more mature steers cautions that other factors may be important. In fact, the smaller (and nonsignificant) difference between the two supplement types with the Old compared with the Young steers suggests that growth of these more mature steers was independent of whether the energy was provided from either an additional fermentable energy source or through stimulus in energy intake via additional protein supply. Both supplement types provide key factors for microbial protein synthesis in the form of RDN and DOM, but they also provide potential glucogenic precursors in the form of starch and amino acids, so cause and effect is difficult to ascribe and a combination of factors is likely for the more mature steers. However, it appears that the Young steers had a primary requirement for additional $\mathrm{MP}$, as illustrated by the significant difference between the CSM and Bar treatments for this age group.

The higher efficiencies of energy use with Bar compared with MUP with both steer age groups are in agreement with the findings of McLennan et al. (2017) for young steers. The relevant 'virtual' $\mathrm{k}_{\mathrm{g}}$ values for Bar and MUP diets in Exp2 were 0.46 and 0.28 for Young steers and 0.47 and 0.40 for Old steers, respectively, which were within the normal range and similar to those of 0.47 and 0.29 recorded by McLennan et al. (2017) for young steers given similar Bar- and MUP-based diets.

The estimated maintenance requirements for Young and Old steers, averaged across experiments, of 21.7 and $40.3 \mathrm{MJ} /$ day or 417 and $423 \mathrm{~kJ} / \mathrm{kg} \mathrm{W}^{0.75}$.day, respectively, were $\sim 13.7$ and $7.6 \%$ lower than those estimated using equations encompassed in the Australian feeding standards ( 483 and $458 \mathrm{~kJ} / \mathrm{kg} \mathrm{W}^{0.75}$.day; NRDR 2007). These higher estimates of the feeding standards, 
relative to values estimated here experimentally, could explain in part their tendency for under-prediction of growth rates of cattle fed tropical forage diets (McLennan and Poppi 2012; McLennan 2014). The comparable respective maintenance requirements predicted by ARC (1980; table 3.23) for Young and Old steers, excluding the small activity allowance, were 529 and $493 \mathrm{~kJ} / \mathrm{kg} \mathrm{W}^{0.75}$.day, respectively, these higher values probably reflecting their derivation primarily using Bos taurus cattle.

The growth rate trends relative to ME intake shown in Fig. 7 suggests that the main steer age-related difference in supplement response was the displacement of the two groups in energy requirements for maintenance, which was largely sustained across the full supplement intake range, such that the Old steers required $\sim 20 \mathrm{MJ} /$ day more energy as supplement and/or hay on average to attain the same $W$ gain as their Young counterparts. In practical terms these findings indicate that the conversion of supplement to additional W gain $(\mathrm{kg} / \mathrm{kg})$ was relatively similar for young and mature-aged cattle, as discussed earlier, and in contrast to our original hypothesis that responses by young cattle would be steeper. It is important to remember that these effects on $\mathrm{W}$ change are not just attributable to supplement intake but are also influenced by the effects of supplement on hay intake and their consequences for total ME intake.

\section{Rumen- and blood-N indices}

The steep linear increase in $\mathrm{NH}_{3}-\mathrm{N}$ concentration in rumen fluid of Young steers fed increasing amounts of the CSM supplement, as measured $3 \mathrm{~h}$ after feeding in Exp1, is consistent with that reported in the previous study (McLennan et al. 2017) albeit that the range of supplement intakes was only half that used previously. This earlier study showed that despite the once-daily feeding regime and the relatively rapid consumption of the CSM supplement, elevated concentrations of $\mathrm{NH}_{3}-\mathrm{N}$ in the rumen were maintained for $24 \mathrm{~h}$ after the supplement was offered, thereby providing a continuous source of additional RDN for the rumen microbes. As discussed above, previous research has shown that the protein of CSM has relatively high degradability in the rumen, with values of 0.71-0.79 reported (AFRC 1993; Moss et al. 1998; McLennan 2004), and our results support this proposition. The elevated rumen concentrations of $\mathrm{NH}_{3}-\mathrm{N}$ were accompanied by corresponding linear increases in PUN concentration $3 \mathrm{~h}$ after feeding in the present work and in McLennan et al. (2017), the main difference being the range in PUN concentration, which was consistent with the 2-fold difference in range of intakes of CSM supplement between studies. For an intake of the CSM supplement of $7.5 \mathrm{~g} / \mathrm{kg} \mathrm{W}$. day, the predicted PUN concentration were 16.8 and $11.2 \mathrm{mg} / \mathrm{dL}$ for Exp1 and McLennan et al. (2017), respectively.

These similarities between studies did not apply as closely to the Bar-based supplements fed to younger steers. Despite the Bar mixes being fed over a similar intake range, a much steeper increase in rumen $\mathrm{NH}_{3}-\mathrm{N}$ concentration relative to supplement intake (at $3 \mathrm{~h}$ ) was apparent in the early study (McLennan et al. 2017) where the urea was included in the Bar mix compared with the present study (Exp1) where it was mixed with the hay. For instance, the estimated $\mathrm{NH}_{3}-\mathrm{N}$ concentrations at $3 \mathrm{~h}$ post- feeding were 201 (McLennan et al. 2017) and $57 \mathrm{mg} / \mathrm{L}$ (Exp1) for intakes of $10 \mathrm{~g} / \mathrm{kg} \mathrm{W}$.day of the barley-based supplements, which reflects the much slower consumption of urea in Exp1 in keeping with its protracted intake throughout the day. The corresponding PUN concentration for barley-supplemented young steers was also lower in the present Exp1 and Exp2, at 3.9 and $7.6 \mathrm{mg} / \mathrm{dL}$ compared with $13.2 \mathrm{mg} / \mathrm{dL}$ in McLennan et al. (2017), presumably also as a result of this slow uptake of urea. Although the method of feeding the urea appears to have had an overall effect on the availability of $\mathrm{N}$ to the steers other factors such as the rate of uptake of $\mathrm{NH}_{3}-\mathrm{N}$ by microbes linked with the variable rates of intake and fermentation of the energy sources in the rumen, and differences in the synchrony of fermentable energy and $\mathrm{NH}_{3}-\mathrm{N}$ supply (Sinclair et al. 1995) and of recycling of urea to the rumen (Lapierre and Lobley 2001) may have contributed. Nevertheless, it is significant that despite these differences in feeding method and concentration of the various metabolites, the growth rate responses with the Bar supplements were remarkably similar, with the slope of the regression lines describing growth against supplement intake being $0.062,0.059$ and 0.077 for Exp1, Exp2 and McLennan et al. (2017), respectively. The corresponding regression slopes for the MUP treatments in Exp2 and McLennan et al. (2017) were also similar $(0.033$ and 0.043$)$ but there also appeared to be smaller differences in PUN concentration for steers receiving these supplements $(5.3$ and $8.5 \mathrm{mg} / \mathrm{dL}$ for an intake of $10 \mathrm{~g} / \mathrm{kg} \mathrm{W}$. day, respectively), perhaps because the urea was included in the MUP mix in both. However, the supplement used in Exp2 also contained a small amount of copra meal.

The general trends in relation to rumen $\mathrm{NH}_{3}-\mathrm{N}$ and PUN concentrations were similar for the Old steers to those described above for Young steers, although PUN concentrations were generally higher than for their Young counterparts, with the exception of the MUP supplement in Exp2, perhaps resulting from differences in the rate of intake of supplement and hay by the different aged steers. In summary, it is clear that growth of steers fed CSM at even low to moderate levels will not be limited by RDN supply for microbial protein synthesis, but may be limited by the availability of fermentable energy (McLennan et al. 2017), whereas with the energy sources there is a greater risk of not providing sufficient RDN for utilisation of the readily fermentable energy.

\section{Conclusions}

The results of these experiments provide support for our previous work in defining the response curves to intake of various commercially important supplements for young steers. The combined dose response curves in Fig. 1 of this study and fig. 1 of McLennan et al. (2017) can be used to assist in formulating rations for practical feeding scenarios, especially for comparing supplement types. Our current response curves can also be used to inform similar ration formulation for older steers to meet specified growth targets. Such information, including the comparison between steers of different ages, was not previously available in this dose response format.

From a practical viewpoint, the equations in Table 2 describing the growth responses by cattle of different ages to supplement intake expressed in absolute units ( $\mathrm{kg} /$ day), indicating 
only small differences between age groups, are of particular interest. These indications of similarities in supplement responses for Young and Old steers, despite $\sim 2$-fold difference in $\mathrm{W}$, were unexpected and seemingly inconsistent with theoretical expectations, but were supported by energy transactions. However, the results probably largely reflect the true differences in the physiological states of the two age groups of steers at the commencement of feeding (see earlier), where the differences in the types of tissue deposited and thus the requirements for nutrients of the two age groups were not as extreme as initially expected. We believe these steers were typical of cattle of similar ages on low-productivity native pasture grazing systems across much of northern Australia. In other higher-growth regions, steers of the same age as the Old steers may well have been of heavier $\mathrm{W}$ and have attained mature skeletal size, and thus be entering a phase of high fat deposition. Thus, any feeding program should take into consideration the growth potential of the region and the progress of the animal towards achieving mature body size, including its body condition at the start of feeding.

\section{Acknowledgements}

The financial support of Meat and Livestock Australia and the Australian Centre for International Agricultural Research is gratefully acknowledged. This project was only possible with the support, financial and otherwise, of the Department of Agriculture and Fisheries and the University of Queensland. We especially thank the management and staff of Brian Pastures Research Station for their enthusiastic assistance with the two experiments, as well as Mr Jim Kidd for expert technical assistance and Ms Kiri Broad for her help with some of the sampling. Special thanks to Dr Tony Swain and Dr David Mayer for their expert advice on the experimental design and at various stages of the statistical analysis of the results and to the various chemists including Mr Peter Isherwood, Mr Peter Martin, Mr Brian Burren and Mr Adam Pytko for biochemical analyses. C. H. Pham was in receipt of a John Allwright Fellowship.

\section{References}

AFRC (1993) 'Energy and protein requirement of ruminants.' (CAB International: Wallingford, UK)

Always SE, Gonyea WJ, Davis ME (1990) Muscle fiber formation and fiber hypertrophy during the onset of stretch-overload. American Journal of Physiology. Cell Physiology 259, C92-C102.

AOAC (1980) 'Official methods of analysis.' (Association of Official Analytical Chemists: Washington, DC)

ARC (1980) 'The nutrient requirements of ruminant livestock.' Technical review by the Agricultural Research Council working party. (Commonwealth Agricultural Bureaux: Farnham)

Berg RT, Butterfield RM (1968) Growth patterns of bovine muscle, fat and bone. Journal of Animal Science 27, 611-619.

Bortolussi G, McIvor JG, Hodgkinson JJ, Coffey SG, Holmes CR (2005) The northern Australian beef industry, a snapshot. 3. Annual liveweight gains from pasture based systems. Australian Journal of Experimental Agriculture 45, 1093-1108. doi:10.1071/EA03098

Bowen MK (2003) Efficiency of microbial protein production in cattle grazing tropical pastures. PhD Thesis. University of Queensland, St Lucia.

Brody S (1945) 'Bioenergetics and growth.' (Reinhold Publishing Corporation: New York)

Butler-Hogg BW, Cruickshank GJ (1989) The effects of environmental factors on growth and development. In 'Meat production and processing'. Occasional Publication No. 11. (Eds RW Purchas, BW
Butler-Hogg, AS Davies) pp. 87-101. (New Zealand Society of Animal Production: Wellington, NZ)

Chase CC, Hibberd CA (1987) Utilization of low-quality native grass hay by beef cows fed increasing quantities of corn grain. Journal of Animal Science 65, 557-566.

Dixon RM, Stockdale CR (1999) Associative effects between forages and grains: consequences for feed utilisation. Australian Journal of Agricultural Research 50, 757-773. doi:10.1071/AR98165

Dolberg F, Finlayson P (1995) Treated straw for beef production in China. World Animal Review 82, 14-24.

Fordyce G, Coates R, Debney M, Haselton S, Rebgetz R, Laing AR, Cooper NJ, Hall R, Holmes WE, Doogan V (2009) A systems evaluation of high-input management using fortified molasses for beef production in Australia's dry tropics. Animal Production Science 49, 177-191. doi:10.1071/EA07225

Freer M, Moore AD, Donnelly JR (2012) The GRAZPLAN animal biology model for sheep and cattle and the GrazFeed decision support tool. CSIRO Plant Industry Technical Paper (revised December 2012). Available at http://www.grazplan.csiro.au/files/TechPaperMay12.pdf [Verified 10 November 2015]

Genstat (2015) 'Genstat for Windows, Release 16.1.' (VSN International Ltd: Oxford)

Klevesahl EA, Cochran RC, Titgemeyer EC, Wickersham TA, Farmer CG, Arroquy JI, Johnson DE (2003) Effect of a wide range in the ratio of supplemental rumen degradable protein to starch on utilization of lowquality, grass hay by beef steers. Animal Feed Science and Technology 105, 5-20. doi:10.1016/S0377-8401(03)00057-9

Köster HH, Cochran RC, Titgemeyer EC, Vanzant ES, Abdelgadir I, St-Jean G (1996) Effect of increasing degradable intake protein on intake and digestion of low-quality, tallgrass-prairie forage by beef cows. Journal of Animal Science 74, 2473-2481.

Lapierre H, Lobley GE (2001) Nitrogen recycling in the ruminant: a review. Journal of Dairy Science 84(Suppl.), E223-E236. doi:10.3168/jds. S0022-0302(01)70222-6

MacRae JC, Lobley GE (1982) Some factors which influence thermal energy losses during the metabolism of ruminants. Livestock Production Science 9, 447-456. doi:10.1016/0301-6226(82)90050-1

McCollum FT, Horn GW (1990) Protein supplementation of grazing livestock: a review. The Professional Animal Scientist 6, 1-15.

McLennan SR (2004) More effective supplements for the northern beef industry. Final report. Meat and Livestock Australia Ltd, No. NAP3.122. Available at http://www.mla.com.au/Research-and-development/SearchRD-reports/RD-report-details/Productivity-On-Farm/Developing-ImprovedSupplementation-Strategies/2005 [Verified 3 March 2016]

McLennan SR (2014) Optimising growth paths of beef cattle in northern Australia for increased profitability. Final report. Meat and Livestock Australia Ltd, No. B. NBP.0391. Available at http://www.mla.com. au/Research-and-development/Search-RD-reports/RD-report-details/ Productivity-On-Farm/Optimising-growth-paths-of-beef-cattle-in-northernAustralia-for-increased-profitability/372 [Verified 3 March 2016]

McLennan SR, Poppi DP (2012) Application of nutrient requirement systems to grazing cattle, with and without supplements. In 'Proceedings of the 4th international symposium of beef cattle production, 2012'. (Eds SC Valadares Filho, MF Paulino, PVR Paulino, AG Silva, D Zanetti, LF Prados, LV Barros, LHP Silva, MA Fonseca, PDB Benedeti) pp. 95-122. (Universidade Federal de Viçosa: Viçosa, Brazil)

McLennan SR, Bolam MJ, Kidd JF, Chandra KA, Poppi DP (2017) Responses to various protein and energy supplements by steers fed low-quality tropical hay. 1. Comparison of response surfaces for young steers. Animal Production Science 57, 473-488. doi:10.1071/AN15659

Moore JE, Brant MH, Kunkle WE, Hopkins DI (1999) Effects of supplementation on voluntary forage intake, diet digestibility, and animal performance. Journal of Animal Science 82, 122-135. 
Moss RJ, Buchanan IK, Casey ND, Matschoss AL, Martin PR (1998) Degradability of protein concentrates available in north Australia. Animal Production in Australia 22, 340.

NRC (1996) 'Nutrient requirements of beef cattle.' (National Academy Press: Washington, DC)

NRDR (2007) 'Nutrient requirements of domesticated ruminants.' (CSIRO Publishing: Melbourne)

Ørskov ER (1970) Nitrogen utilization by the young ruminant. In 'Proceedings of the 4th nutrition conference for feed manufacturers, University of Nottingham'. (Eds H Swan, D Lewis) pp. 20-35. (J and A Churchill: London)

Owens FN, Garza J, Dubeski P (1991) Advances in amino acid and N nutrition in grazing ruminants. In 'Proceedings 2nd grazing livestock nutrition conference'. (Eds FT McCollum, MB Judkins) pp. 109-137. (Oklahoma State University: Stillwater)

Perdok HB, Leng RA (1990) Effect of supplementation with protein meal on the growth of cattle given a basal diet of untreated or ammoniated rice straw. Asian-Australasian Journal of Animal Sciences 3, 269-279. doi:10.5713/ajas. 1990.269

Poppi DP (1990) Manipulation of nutrient supply to animals at pasture: opportunities and consequences. In 'Proceedings of 5th Asian-
Australasian Association of Animal Production (AAAP) Animal Science Congress, Volume 1, Taipei, Taiwan'. pp. 40-79. (AAAP: Chunan, Miaoli, Taiwan)

Ryan WJ (1990) Compensatory growth in sheep and cattle. Nutrition Abstracts and Reviews 60, 653-664.

Schiere JB, de Wit J (1995) Feeding urea ammonia treated rice straw in the tropics. II. Assumptions on nutritive value and their validity for least cost ration formulation. Animal Feed Science and Technology 51, 45-63. doi:10.1016/0377-8401(95)00678-G

Sinclair LA, Garnsworthy PC, Newbold JR, Buttery PJ (1995) Effects of synchronizing the rate of dietary energy and nitrogen release in diets with a similar carbohydrate composition on rumen fermentation and microbial protein synthesis in sheep. The Journal of Agricultural Science 124, 463-472. doi:10.1017/S0021859600073421

Wickersham TA, Cochran RC, Titgemeyer EC, Farmer CG, Klevesahl EA, Arroquy JI, Johnson DE, Gnad DP (2004) Effect of postruminal protein supply on the response to ruminal protein supplementation in beef steers fed a low-quality hay. Animal Feed Science and Technology 115, 19-36. doi:10.1016/j.anifeedsci.2004.03.005 